\title{
Képekben elbeszélt múlt - Mesterházy Jenő
}

\author{
JANEK Nó́mi - BALOg BeÁta
}

Eötvös Loránd Tudományegyetem, Tanító- és Óvóképző Kar

\begin{abstract}
A szerzők által végzett Mesterházy-hagyaték feldolgozása az Eötvös Loránd Tudományegyetem Pedagógiai és Pszichológiai Karon (ELTE-PPK) 2015-ben sikeresen megpályázott kutatás-támogatási pályázatának keretén belül valósult meg. A hagyaték az ELTE Tanitó- és Óvóképző Karának Könyvtárában található, a kutatás, vizsgálódás is itt zajlott. A tanulmányban egy "hétköznapi pedagógus” életútját kívánják megismerni, megismertetni, aki akár példaként, mintaként is szolgálhat a ma is aktív vagy leendö pedagógusok számára, emellett segithet egy adott történelmi idöszakot jobban, részleteiben is megismerni a személyes dokumentumok elemzésének segitségével, melyek az életút, tapasztalatok elmesélését tartalmazzák. Mesterházy Jenö nagy gondot forditott arra, hogy életét és szakmai útját is dokumentálja, hiszen nagyon sok kéziratát is megtartotta (publikációk, elöadások vázlatai, naplói) a nyomtatásban megjelentek mellett, valamint magán-és szakmai levelezéseit is gondosan megörizte, nem beszélve a nagyszámú fotógyüjteményéröl. Ennek következtében hat nagy témakör mentén mutatják be a szerzők a pedagógus életútját dokumentumelemzés módszerével és ikonográfiai feldolgozással: Mesterházy Jenö, mint: Férj és apa; Pedagógus; Cserkészcsapat vezetője; A népmüvelés zászlóvivöje; A katonaférfi; illetve Mesterházy Jenö, a fotós.
\end{abstract}

Kulcsszavak: hagyaték-feldolgozás, dokumentumelemzés, ikonográfia, életút, pedagógus

\section{Bevezetés $^{1}$}

A huszadik század végétől egyre inkább növekszik a biográfia, az élettörténet, életútelemzés iránti érdeklődés, kutatási módszerként történő alkalmazása (Kövér, 2000). Oka lehet a hétköznapi élet felé való fordulás, a nagy, neves (politikai) személyek helyett a „hétköznapi ember” életébe való betekintési szándék, mely által a történelmi eseményeket konkrét tapasztalatokkal színessé tehetjük, bővíthetjük, alátámaszthatjuk, cáfolhatjuk (Pénzes, 2013). Jelen tanulmányban is egy „hétköznapi pedagógus” életútját kívánjuk megismerni, megismertetni, hiszen akár példaként, mintaként is szolgálhat a ma is aktív vagy leendő pedagógusok számára, emellett

\footnotetext{
${ }^{1}$ Az általunk vizsgált Mesterházy Jenő-hagyaték az Eötvös Loránd Tudományegyetem Tanító- és Óvóképző Karának Könyvtárában található, a kutatást, vizsgálódást is itt végeztük el. Jelenleg a könyvtárban megtekinthető Mesterházy Jenő életútjáról szóló poszter, melyet a 2015-ös Országos Neveléstudományi Konferencián volt alkalmunk bemutatni, illetve ugyanitt a hagyatékból kiállítva láthatunk néhány fotót, kéziratot, emléket.
}

segíthet egy adott történelmi időszakot jobban, részleteiben is megismerni életutak, tapasztalatok elmesélése által (oral history).

\section{Életrajzi adatok}

1888. július 24-én született Neusiedlersee (Nezsider, Neusiedl am See) nevű osztrák kisvárosban. Édesapja Mesterházy Gyula (Apóként nevezi), édesanyja Schätzel Terézia (Anyóként nevezi), akik foglalkozásáról a hagyaték hiányzó elemei miatt nem sok információ tudható meg. Ami kiderült számunkra, hogy három fivére és egy Joli nevü húga volt, egyik fivérével több levélváltása a hagyatékban is megmaradt. Jenő gyermekkorát Kapuváron töltötte, ahol polgári iskola IV. osztályának bizonyítványát szerezte meg 1902. március 27-én.

1902. április 24-én tanítói pályaalkalmasságról kapott igazolást, majd ugyanezen év augusztus 10-én felvételt nyert a Csurgón lévő tanítóképző intézetbe, amelyben 1906. március 23-án szerzett oklevelet. Eztán polgári iskolai tanítóképzőbe járt 1907 és 1910 
között, ahol tornatanítói oklevelet szerzett, majd egyetemi indexe alapján tudhatjuk, hogy tovább folytatta tanulmányait és tanítóképzőintézeti tanárnak tanult 1910-1912 között. 1912-ben bizonyítványt szerzett didaktikai gyakorlatairól, majd 1913. június 18-án segédtanári kinevezést kapott Modorra. 1914től rendes tanár lett, július 1-től pedig Kolozsvárra helyezték át. 1913-ban eljegyezte Baló Juditot, akinek édesapja dr. Baló József a budapesti I. kerületi állami tanítóképző igazgatója volt (1904-1916), ahol később maga Mesterházy is dolgozott tanárként. Egy lánygyermekük született, akit legtöbbször Jutkaként emleget. Születésének időpontja ismeretlen a hagyaték hiányossága miatt. Saját családjának története is érdekelte, mely kutatásával kapcsolatosan levelezéseket folytatott, melyek sajnos szintén a hagyaték hiányzó részei közé tartoznak.

1909. március 24-én katonai bevonulásával kapcsolatosan halasztást kért, későbbi irományai alapján (1910) tudhatjuk, hogy az ifjú Mesterházynak nem nyerte el tetszését a sorköteles katonaság. Pályáját az 1914ben kitörő első világháború szakította meg, amely a sok megőrzött képi és írásos emlék tanúsága szerint fontos állomása lehetett életének. A háború során megfordult Toporontz faluban, Okna kastélyos faluban, valamint a képi hagyatékban Erdély és Bukovina is említésre kerül. Sokat levelezett Anyóval, Apóval (annak 1916-ban bekövetkező haláláig) és Joli húgával. Feleségének is több képeslapot küldött, amelyek érzelmi töltete már a megszólításokból is kiérződik - „drága kicsi feleségem, drága kicsi mindenem". 1923-ban édesanyja alapítványt hozott létre a háborúban elesett két fia emlékére.

1937. január 2-án szakfelügyelői megbízást kapott, majd 1940-ben az Esztergomi Tanítói Továbbképző Tanfolyamot végezte el.

1940. december 1-jén katonakönyvét megkapta, valamint a Tanítóképző 1940/41-es évkönyvéből kiderül, hogy a II. világháborúban két hónapos katonai szolgálaton volt, így a „c. igazgató tanárelnököt” Árpássy Gyula helyettesítette. 1941/42-es tanévben hosszabb ideig betegeskedett, így dr. Wagner Ferenc helyet- tesítette őt. 1944-ben igazgatói megbízást kapott, majd 1945-ben Szociáldemokrata Nevelöi Csoport tagja lett.

1945. június 14-én igazolási nyilatkozatot tett, melynek elbírálásáról nincs a hagyatékban információ, viszont július 5-én fellebbezést nyújtott be a Népbírósághoz a július 2-án hozott döntésük ellen. 1945. december 5-én a budapesti tankerületi hivatal dolgozói kérést intéztek a Népbírósághoz Mesterházy hivatalnoktársuk teljes rehabilitálása érdekében. 1946. január 24-én keletkezett határozat Mesterházy Jenő nyugdíjazásával kapcsolatosan.

1945-1946-ban, majd 1956-1957-ben részletes naplót írt, melyekben az idősödő Mesterházy leginkább naponkénti teendőit jegyezte le.

Mesterházy Jenő 1963-ban hunyt el, felesége Mesterházy Jenőné Baló Judit pedig 1985-ben követte.

\section{Szakmai életút}

Mesterházy Jenő nagyon tevékeny, tág érdeklődési körrel rendelkező tanár volt. Érdeklődött a történelem, földrajz, művészettörténet, képzőművészeti (építészeti, festészeti, szobrászati) emlékek iránt ${ }^{2}$. 1912-től vidéken gyakorolja tanítói mesterségét. 1919-ben lett Tanítóképző Intézeti tanár Budapesten.

1921. március 18-án nevezték ki a Tanítóképző-intézeti Tanárok Országos Egyesületének (továbbiakban: TITOE) anyagi ügyeinek állandó bizottsága előadójává. A TITOE 1889. április 16-án alakult meg azzal a céllal, hogy a tanítóképzés minden területére vonatkozó fontosabb kérdésben a közoktatási kormány az Egyesület meghallgatásával döntsön (Raicsné, é.n.). Tehát azért, hogy hozzájáruljon a tanítóképzés és a népiskolai nevelés és oktatás színvonalának emeléséhez. Pornói

\footnotetext{
2 Lásd: Padányi-Frank, 1941: Mesterházy Jenő: Történelem, magyar, földrajz szakos, tornatanári okl. rendes tanár, c. igazgató. A történelmi szertár és könyvtár őre. Tanulmányi felügyelő. A soproni evang. tanítóképző-intézet képesítővizsgálatain kormányképviselő. Az önképzőkör felső tagozatának tanárelnöke, Lakik: XII., Királyhágó-tér 9.
} 
Imre a következőképp foglalja össze tömören a TITOE jelentőségét: „A Tanítóképző-intézeti Tanárok Országos Egyesülete vetette fel a képzők szakiskolai jellege kidomborításának szükségességét, s a gyakorlóiskolák átalakítását a képzés céljainak megfelelően. Ezeken kívül javasolták a tanítójelöltek felvételének módosítását, a tanítóképesítés rendezését $\mathrm{s}$ a felekezeti képzők tanárainak fizetésrendezését. Felvetették az egységes tanítóképzés és egységes képesítés gondolatát is, melyek a felekezeti és az állami intézmények közötti különbségek kiküszöbölését célozták. Ezek mellett felmerült az önálló tankerületi szakfelügyelet reformjának szükségessége s a tanítóképző-intézeti érettségi gondolata is." (Pornói, é.n.). Az Egyesületi gyülések hatására sorra jelentek meg a tanítóképzés fejlesztését sürgető cikkek, pszichológia és pedagógia oktatásának aktuális kérdéseivel foglalkozó előadások, írások (Pukánszky és Németh, 2001). Mesterházy Jenő apósa, Baló József volt a TITOE elnöke, aki szintén nagy hangsúlyt fektetett e célok megvalósítására (Kovács, 2011).

Mesterházy Jenő kiemelt érdeklődési köre volt a történelem tudománya, melyet a hagyatékában található kéziratai, publikációi ${ }^{3}$, saját kezűleg készített fotói egyaránt bizonyítanak. Ha egy idővonalon előrehaladva ábrázolnánk e kiemelkedő aspektusát életének, a következő évek lennének a meghatározóak: 1928-ban szerződést kötött a Franklin-Társulattal tanítóképző-intézeti történelem tankönyvek írására. 1935. február 8-án pedig a Budapesti Népfőiskolai Széchenyi-Szövetség köszönetet mond igazi magyar "lelkiséggel telített erkölcsnemesíto" értékes történelmi előadásáért." 1940-ben a Fővárosi Pedagógiai Szeminárium igazgatója

\footnotetext{
3 Tanulmányokat írt a Magyar Tanítóképzőbe; Pedagógiai Szemináriumba (Mátyás király emlékei, A budavári Honvédemlék) ; Magyar Lélekbe (A MezőgazdaságiMúzeum, A Széchenyi-emléktábla. Emlékezés Mátyás királyról); A Napkeletbe (Budavár Zsigmond korabeli emlékei). A líceum és leánylíceum 1. és II. osztálya számára megírta az egyetemes történelem kézikönyvét (Évkönyv, 1939/40).
}

felkéri előadássorozat megtartására Budapest műemlékeiről, mely szintén mutatja történelemszeretetét és mely müemlékekről szintén számos fotó található az ELTE-TÓK Könyvtárában lévő Mesterházy-hagyaték anyagában. Egy évvel később, 1941-ben felkérésre ugyanerről a tanítók továbbképző tanfolyamán tart előadást. 1943-ban ismét szerződést köt a Franklin-Társulattal a „Magyar Életrajzok" sorozatban a Thököly Imre c. kötet megírására.

Munkássága, tevékenységei eredményességért és megbecsüléseképp több elismeréssel is jutalmazták élete során.

A Budapest Székesfőváros Iskolánkívüli Népművelési Bizottsága több éves kiváló eredményű oktatói és nevelői munkásságáért köszönetét és elismerését fejezte ki 1925. június 20-án.

1933. március 19-én a Budapest Székesföváros Népművelési Bizottsága 10 éves fennállása alkalmából a főváros népművelése terén kifejtett érdemes és önzetlen munkájáért teljes elismerését fejezi ki és bronz emlékérmét adományozza. E tevékenysége még 3-4 év elteltével és az elismerés után is meghatározó volt a tanító számára, melyről egy évkönyv így számol be: „Kultúrestek: Ebben az évben népművelési előadásaink, illetőleg kultúrestéink sorozatát a szomszédállamok és a forrongó Spanyolország megismertetésének szenteltük, egy előadásban pedig nevelési kérdéssel foglalkoztunk. Az előadások és azok kísérő műsora szélesebb körben is nagy tetszést arattak. Úgy láttuk, hogy kultúrestéinkkel a nagyvárosi iskolánkívüli népművelés helyes útján jártunk. A kultúresték rendezője ez évben Kishonti Barna tanár volt, az egyes kérdések előadói pedig: Padányi-Frank Antal dr. igazgató, Knébel Miklós dr. plébános, Garamvölgyi Ervin, Lux Gyula dr., Mesterházy Jenő és Vineze Sándor tanárok voltak" (PadányiFrank, 1937).

Mesterházy Jenő tanári pályája során számos tanulmányi kirándulást szervezett növendékeinek értelmi, érzelmi, esztétikai nevelési célzattal, melyről egy 1930/31-es iskolai évkönyvben a következőképpen ír: 
„Ebben az évben Sopronba rendeztünk nagyobb kirándulást, amelyröl Mesterházy Jenö tanár a következökben számol be. Intézetünk már a múltban is tisztában volt a kirándulások nagy jelentöségével úgy az értelmi, mint az esztétikai nevelés szempontjából. Amikor csak alkalmunk volt rá, felkerestük növendékeinkkel azokat a helyeket, melyek akár természeti, akár müvészi szépségeket vagy egyéb tanulságokat egyesitenek magukban. Ilyen helyek böséggel vannak fóvárosunkban és közeli környékén; de ezek mellett nem hanyagolhatók el hazánk távolabbi vidékei és tipikus tájai, melyek megtekintése a földrajzi tanulmányok egyik legkitünőbb megerösitooje, eszköze. Ennek érdekében minden évben igyekszünk egy ú. n. nagyobb kirándulást megszervezni, mely legalább háromnégynapos. Sajnos, ezen igyekezetnek erős akadályozói azok a szerény anyagi körülmények, melyek intézetünk növendékeinek túlnyomórészét még a legszükségesebbek megszerzésében is próbára teszik. Nehéz tehát nálunk nagyobb kirándulást szervezni, bármily szerényre is tervezzük annak költségeit. Az 1929/30. tanév folyamán egy ilyenre irányuló kísérlet nem sikerült és a mostani tanév folyamán is csak 21 növendék vállalkozott arra, hogy a négynapos kirándulás fejenkénti költségeit igyekszik elöteremteni. Annak összege pedig minimálisan 20 pengöben volt megállapitva. - A kirándulás célja Sopron. volt, megcsonkitott hazánk nyugati határszéle, tehát meglehetösen távoli pont fóvárosunktól." (PadányiFrank, 1931).

Több fotó készült a Mesterházy által szervezett tanulmányi kirándulásokon, a Magyarországi Tanítók Eötvös-Alapja vezetői köszönetet is mondanak 1935 szeptemberében a vidéki tanítók nyári tanulmányi kirándulásain kifejtett értékes, önfeláldozó munkásságáért.

Mesterházy Jenő számos rádióelőadást tartott különböző témákban. 1935 novemberében az Országgyűlési elnök tanácsosa köszönetet mond rádióelőadásaiért.

A Pestvármegyei Népművelés felelős szerkesztője köszönetet mond 8 évi eredményes munkatársi feladatainak ellátásáért 1936. október 13-án.

1937-ben Mesterházyt a Társadalmi Egyesületek Szövetsége Jubileumi Érdemkeresztjével tüntették ki.

Az Országos Közoktatási Tanács köszönetét és elismerését fejezi ki az 1938. XIII.tc. végrehajtásával kapcsolatos munkálatok elvégzésében való buzgó és eredményes részvételéért. $E$ törvénycikk a gyakorlati irányú középiskoláról rendelkezett. Négy részre tagolódott: első rész: általános rendelkezésekről (pl. középiskolák fajtái), második rész: a líceumról, harmadik rész: a gazdasági középiskoláról és az utolsó rész vegyes és záró rendelkezésekről (intézményelnevezések, tanári képesítések) adott számot ${ }^{4}$.

1943. február 22-én a Fővárosi Tudósító köszönetét nyilvánította Mesterházy kritikusi közreműködéséért.

Vizuális alkata és műkedvelő volta alapján előadásait előszeretettel színesítette vetített képekkel pl. 1938-ban a Pázmány Péter Tudományegyetem Szabad Egyetemén a második félév előadásainak sorozatában az 1937-ben tartott Párizsi Világkiállításról adott elő a pedagógus.

Gyakorlatias személyisége mellett az elméleti, tudományos szférában is helye volt, melyről publikációi tanúskodnak (például folyóiratokban megjelent cikkei, így az 1940 októberében a Földgömb címü lapban Edinburgh, az északi Athén címmel; önálló kiadványai így történelemtankönyvei).

\section{A Budapesti I. kerületi állami tanítóképző Mesterházy idején}

A tanitóképzés hazánkban immáron közel 150 éves múltra tekint vissza a mai ELTE Tanitóés Óvóképző Karának életében. Éppen ezért érdemes röviden áttekinteni hogyan alakult a sorsa a képzésnek és magának a képzőintézménynek abban az időszakban, amikor Mesterházy Jenő a képző tanára volt. Ugyanakkor érintőlegesen említésre érdemes Baló József is, aki Mesterházy feleségének, Baló Juditnak

\footnotetext{
${ }^{4}$ lásd bővebben: http://www.1000ev.hu/index.php?a=3\& param $=8068$
} 
Képekben elbeszélt múlt - Mesterházy Jenő

az édesapja volt és egyben 1916-ig az intézet igazgatói posztját is betöltötte.

Baló József nevéhez füződik az intézménynek ma is otthont adó épület felállításának szervezési munkája. 1909-ben kezdték el építeni, 1911-re teljes egészében el is készült az akkori Mozdony utca, Hantos út és Tatár utca sarkán. A homlokzati és keleti szárnya adott otthont a tanítási célzatú tevékenységeknek, nyolc tanteremmel, tornateremmel, zeneés díszteremmel, 18 szertári helyiséggel és 6 zongora-gyakorlószobával. Ezeken kívül található volt benne négy iskolaszolga lakószobája, igazgatói lakás és orvosi rendelőszoba is.

A nyugati szárnyban az internátus- és konviktushelyiségeket helyezték el, három hálótermet, két betegszobát, nappali termet, mosdószobát, négy dolgozószobát és a nevelők lakásait. Az alagsorban pedig zuhanyzó volt a képző növendékei számára.

Az udvar nagysága 1600 négyzetméter területű volt, melyben botanikus kert és díszkert is található volt, valamint nyári tornakertként és játszóudvarként is alkalmas volt.

Az intézet nyugodt és szakmailag pezsgő életét az I. világháború bolygatta fel. 1915ben befogadta a polgári iskola tanítóképzőjének gyakorlóiskoláját, 1916-ban a torna- és zeneszakcsoportját, majd a dévai tanítóképzőt is. Az intézet tanárai és növendékei közül sokaknak be kellett vonulniuk a háborúba, akik közül harmincan nem térhettek haza a frontról.

1916-ban új igazgató került az intézet élére, mely posztot Quint József töltötte be. A Tanácsköztársaság kikiáltása idején az épületbe a rendőrség költözött be, ami miatt a képzést ideiglenesen az Alkotás utcai Tanitói Árvaházba kellett költöztetni. 1920/21-ben kaphatta vissza otthonát, de sajnálatos módon az addig összegyüjtött felszerelés maradéktalanul elveszett.

Ebben az időszakban már a felsőfokú tanítóképzés igénye is körvonalazódni látszott, ám ennek bevezetése csak sokkal később, a század közepén történt meg (1959-ben), hiszen a tantervjavaslatok közül a német mintát követték, így maradt a középfokú tanítóképzés, öt évfolyammal.
Az 1925-ben meghatározott népiskolai tanterv a gyakorlatiasságot és a hivatástudatot emelte ki a tanítók képzésében. Az 1923-1938 közötti időszak szintén a szakmai sikerek és az országos „elöljárás” idejének tekinthető. Quint több országos egyesületben működött aktívan közre és a15 kötetes vezérkönyvsorozat is a nevéhez köthetö.

1929-től Padányi-Frank Antal váltotta az igazgatói poszton, ahol már 1919-től tanárként dolgozott.

A gyakorlati képzésben a meglévők mellett új formák is megjelentek, így szülői értekezletet tartottak a tanítójelöltek, madarak és fák napjának ünneplését is fontosnak tartották. Versenytanítások is megrendezésre kerültek évente, ami a tanítói hivatástudat elmélyítésében fontos szerepet töltött be. Ezen kívül évente pedagógiai kirándulást szerveztek, valamint havonta egyéb kirándulásra is sor került. 1927-ben Apáczai cserkészcsapat alakult az intézetben, 1930-ban pedig Ifjúsági Vöröskereszt. Ebben az időszakban volt maga Mesterházy Jenő is a tanári kar jelentős tagja. 1930-as évek végén ismét előtérbe került a tanítóképzés reformja.

1940-ben Erdély északi részének visszacsatolását követően kultúresteket rendeztek a képzőben Erdély megismerése céljából, melyen Mesterházy Jenő is előadást tartott számos előadóval és művésszel egyetemben. 1943/44-ben a II. világháború miatt akadozott a tanítás, többször rendeltek el szünetet.

$\mathrm{Az}$ épület a II. háború ideje alatt német szükség-hadikórháznak adott otthont, így ismét költözni kellett (1944). Ezúttal a Csalogány utcai tanitónóképzőbe, majd a BaárMadas-Inétzetbe (egy hétig) ezt követően pedig a Trefort utcai gyakorlógimnáziumba. E tarthatatlan állapot miatt végül a tanítás szünetelni kényszerült ezen év októberétől.

Az 1944-es ostromban sajnálatos módon súlyosan megrongálódott az épület díszterme, orgonája és szertárai is, mely állományának 70\%-a odalett. A meglévő 98 helyisége közül egy sem maradt ép. Leégett a méhes, az üvegházak szintén tönkrementek. Az intézet páncélszekrényét is kifosztották. A tanári kar és a növendékek 1945-ben közös erővel kezdték meg a romok eltakarítását. A helyreállítás 
Janek Noémi - Balog Beáta

munkálatai az eredetileg eltervezettektől eltérően történtek, a kupolás homlokzati díszítésủ épület és a hatalmas kert sem lett teljesen helyreállítva.

\section{Képekben elbeszélt múlt}

Metodológia

\section{Hagyaték anyaga, feldolgozásának fontossága, kutatási kérdések megfogalmazása}

A Mesterházy-hagyaték írásos és képi anyagban egyaránt gazdag, amely a többoldalú bemutatását segíti elő mind az egyéni, mind pedig az intézményi történetnek. Mesterházy Jenő nagy gondot fordított arra, hogy életét és szakmai útját is dokumentálja, hiszen nagyon sok kéziratát is megtartotta (publikációk, előadások vázlatai, naplói) a nyomtatásban megjelentek mellett, valamint magán- és szakmai levelezéseit is gondosan megőrizte.

Nem csak szakmai, tudományos érdeklődése volt intenzív, hanem nyitott volt a müvészet, kultúra irányába is, amit sok - ilyen jellegü általa vásárolt kiadvány és kivágott újságcikk is bizonyít. Ezenkívül maga is szívesen foglalatoskodott számára érdekes épületi, tárgyi emlékek megörökítésével, így sok negatív, diakép és papírkép is található a hagyatékban. Ezeket a földrajz és történelem tanítása kapcsán, mint szemléltetésre alkalmas vizuális elemeket is alkalmazta, amely a maga korában minden bizonnyal modern módszernek számíthatott. Sok levelezést folytatott tanítványaival, ami arra enged következtetni, hogy nem csak az óra keretein belül, hanem azon túl is elérhető személy volt számukra. Ezen kívül a tanulók rendszeresen hoztak képeslapot, képeket szeretett tanáruk gyüjteményébe arról a helyszínről, ahol tartózkodtak. Cserkésztáborokban, valamint többféle kirándulásokon is részt vett, ahol - a fennmaradt képi anyagok szerint „idegenvezetői” szerepkört töltött be. Fontosnak tartotta a népmüvelést, több képi forrás is tanúsítja, hogy kirándulásokon vett részt, amelyeket nem diákoknak szervezettek voltak (például a Kerepesi temető látogatása az Aradi vértanúk méltatása céljából).

A családi emlékek is megörzésre kerültek, amelyek között leginkább feleségével és kislányával készült képek láthatók. Mütermi beállított képek és pillanatfelvételek is akadnak a hagyatékban. Igazán gazdagon dokumentált az I. világháborúban töltött időszaka, amely megörökítését maga Mesterházy Jenö is fontosnak tarthatta, hiszen a legtöbb képen szerepel akár csoportban, akár egyedül is. Ez azért is lehetett számára fontos, mert képeslapként szerette volna elküldeni feleségének. A II. világháború már kevéssé követhető nyomon képi emlékekkel.

A képek alapján egy derűs, optimista, életkedvvel teli személyként ismerhető meg Mesterházy Jenő, aki nagy szeretettel viszonyult családjához és a tanítványaihoz is érdeklődve fordult a megmaradt emlékek szerint. Szenvedéllyel szerette műveltségterületeit, így a földrajzot és a történelmet, valamint a művészeteket is, ami hobbijaként tekinthető.

Idősebb korában naplót vezetett, ami talán arra utalhat, hogy a nyugdíjazása után is vágyat érzett arra, hogy írjon és a korábbi tevékeny életét más formában, de aktívan töltse és ezt is megörökítse.

Sajnos a hagyaték elég hiányos föleg a személyi anyagára vonatkozóan, ami nagyban megnehezíti személyének teljes bizonyossággal történő megismerését és megismertetését. Ennek ellenére fontosnak véljük a minél teljesebb körü bemutatást, amelynek fontosságát a következőkben is látjuk.

Az életútelemzés során az adott pedagógus megfontolt döntései, életében lévő spontán történések és a véletlen egybeesések tényeinek keresése és az ezek közötti/mögötti oksági összefüggések keresése történik. Így - csomópontok érzékeltetése, sorsfordulók keresése, döntési helyzetek kiemelése és utólagos elemzése, a véletlenek szerepének felismerése, az életterv tudatosságának mérlegelése, az életút több szempontú értékelése (család, munkahely, szakmai karrier, önértékelés, mások véleménye) valamint a pedagógiai képességek, készségek, tevékenység müvelésének szinvonalára vonatkozóan (szaktudás, pedagógiai tapasztalatok köre, pedagógiai érzékenység, 
pedagógiai helyzetek elemzése, esztétikai igényesség, helyesírás) által (Mikonya, 2011).

Mindezzel összefüggésben, egy konkrét tanítói életút megismerésével fontos feltárandó kérdésnek tekintjük, hogy a 20. század elején milyen volt egy tanító élete, hogy élte meg pályáját, milyen kötelességei voltak, milyen tudományos tevékenységeket folytatott (publikálás, előadás), mivel töltötte szabadidejét, milyen kapcsolata volt kollégáival, tanítványaival. Emellett fontosnak tartjuk kiemelni, hogy milyen volt a magánélete, az a közeg, ahová hazatért, ahol meg tudott pihenni, ahol fel tudott töltődni. Mindezt pedig kiegészítve a tanító személyes fényképeinek ikonográfiai elemzésével, szemléletével kívánjuk bemutatni.

\section{A hagyaték feldolgozásának módszertani lehetöségei - Ikonográfia}

Az egyén életútjának, valamint egy intézmény múltjának és jelenének feltárása nem csak írásos dokumentumok állhatnak rendelkezésre, hanem a képeket is érdemes a kutatás anyagaként kezelni. Ez a nézet egyre kezd teret hódítani a pedagógiai kutatásokban is, melyre bizonyítékként szolgálhat a 2000-res évektől növekvő ikonográfiai és ikonológiai szempontú neveléstörténeti kutatások száma (Mikonya, 2006; Géczi, 2010).

A fénykép egyszerre tárhelye és megteremtője a személyes és kulturális emlékezetnek, a múltat idézi es felépíti (Sturken, 1999) idézi Somogyvári.

„Az ikonográfia a müvészettörténet segédtudományaként vált elismert diszciplínává. Azt vallja, hogy a müalkotás rejtett jelenségek hordozója, amit különféle módszerekkel kell megfejteni. Megalapitó atyjának Erwin Panofskyt tekinthetjük, de az ő munkásságát számos kortárs müvészetelméleti szakíró, így Meyer Schapiro vagy Edgar Wind művei több ponton kiegészítik." (Endrödy-Nagy, 2015, 84. o.)

Michell és Boehm említi, hogy a kép, képiség jelentősége megnőtt, valamint az élet minden területén előtérbe került a képek és szimbólumok használata (Somogyvári, 2013).

Az ikonográfiai és ikonológiai elemzés forrásául szolgálhatnak az intézményi anya- gok mellett a magángyüjtemények is, ezért is tartjuk fontosnak e hagyaték képeinek megismertetését. A Mesterházy-hagyaték leginkább archív fotókat és üveg diapozitívképeket tartalmaz, amelyeket maga Mesterházy Jenő készített. Ezen kívül sajtóban megjelent fotókat is találhatunk, amiket az érdeklődésének megfelelően gyüjtött össze (például a nagy budapesti árvízzel kapcsolatos cikkek, történelmi jellegü írások). A bemutatásunkhoz most kizárólag az archív fényképgyüjteményt használtuk fel.

\section{Eredmény és használhatóság}

A fotók gyűjteménybe helyezése lehetőséget biztosít az intézmény múltjának, pedagógiai értékeinek az összegyűjtésére, rendszerezésére, elérhetővé, valamint kutathatóvá tételére. A tanító- és az óvóképzés múltjának gazdagítására is szolgál, hiszen a képi anyagok segítségével egy adott pedagógiai kultúra is feltárhatóvá válik. Az egyéni életutak feltárásának segítésére is lehetőséget biztosít, akár az intézmény tanárait, oktatói, vezetőit, akár az itt tanuló, végzett hallgatókat tekintve. Az elbeszélt múlttal öszszevetve egy komplex történetté forrhat össze, amely által még inkább megismerhetővé válnak a különböző korszak pedagógiai kultúrái. A képzés és gyakorlat, így az egyén és az intézményi szféra kölcsönhatásai is feltárhatóak.

Collier leírásában a képek elemzésének négy fö lépése lehetséges (idézi: Endrődy-Nagy, 2015. 80. o.), miszerint elsőként a képre rátekintve hagyatkozzunk érzéseinkre, rögzítsük azokat és nézzük az egész adathalmazt egységként. Itt fontos, hogy hagyjuk, hogy minden benyomás felszínre jöjjön, minden kérdést rögzítsünk, ami felmerül bennünk, mert lehet, hogy a későbbi analízisnél fontos irányba terel. Ezután Collier szerint készítsünk kategóriarendszert minden képről, az alapján, hogy mi a célunk, mit szeretnénk feltárni. Majd következzék a konkrét elemzés, részletes leírások, mérés, számolás grafikonokkal és statisztikai számítógépes elemzésekkel, összehasonlításokkal. Végül pedig a szignifikáns elemek megkeresésének fázisa jöjjön, úgy, hogy ismét az egészet nézzük, az összes elemet együtt. Ez alapján írjuk le a konklúziót. 
Collier a vizuális antropológiai képelemzés lényegét mutatja meg. A vizuális antropológia nem más, mint „vizuális rögzités, a jelen és a múlt útjainak leírása bizonyos közösségekben”. A gyakorlat felé orientálódik, arra fókuszál. Felteszi azt a fontos kérdést, hogy mi az, ami hasznos, mi az, ami használható a vizuális kutatásban, melyek az előrevivő elemek, tények. Tulajdonképpen a vizuális antropológia különféle lencséken keresztül vizsgálja a személyes és kulturális identitást (idézi: Endrödy-Nagy, 2015, 78. o.)

Ez azért lehet optimális módszer a rendelkezésünkre álló fotók elemzéséhez, mert bár az elemző érzéseit, benyomásit helyezi fókuszba, mégis egy algoritmust kínál, melynek segítségével ki tudjuk emelni a kép esszenciáját, lényegi elemeit az adott témához, kontextushoz kapcsolódóan. Segítségével több hasonló témájú képet tudunk összehasonlítani. Belting megállapítása szerint „az antropológiai nézőpont nem a technikából indul ki vagy a képalkotás gyakorlatából, hanem új típusú diszkussziót igényel" (idézi: Endrödy-Nagy, 2015, 80. o.) Vagyis a technikai részleteken kívül fontos másfajta nézőpontok bevonása is a képelemzés folyamatába, például az adott társadalmi kontextus, a háttérinformációk, a fotó keletkezési körülményeinek figyelembe vétele. Nagyon fontos, hogy

\section{Mesterházy Jenő - férj és apa}

minden kép többféle módon interpretálható, akár egyetlen módszert alkalmazva is az elemzéséhez, hiszen minden embernek más-más érzései, benyomásai lehetnek egy adott képről. A mi elemzésünk tehát egyfajta megközelítése a hagyaték fotóinak értelmezéséhez.

A képek tartalmának, értelmének feltárásához szükségünk van fogódzókra, kódokra, melyeket meg kell alkotnunk magunknak az elemzés folyamata során (Endrödy-Nagy, 2015).

Tehát a képek elemzéséhez következő lépéseket tesszük meg Collier alapján:

1. Kép leírása - kik vannak rajta, milyen a tárgyi környezet, mit ábrázol

2. Kép üzenetének keresése

3. Kódrendszer

Kép készítésének technikája

Felkészültség

Színtan - fény-árnyék

Tipográfia

Szociokulturális jegyek (ruhák, jelvények)

Esztétika, stílus

Non-verbális kommunikáció

Társas helyzetek

4. Szövegek szerepe

5. Jelentés kialakítása - kortárs valóság

A képek elemzése során e szempontokat az adott kép jellege alapján igyekszünk érvényesíteni.

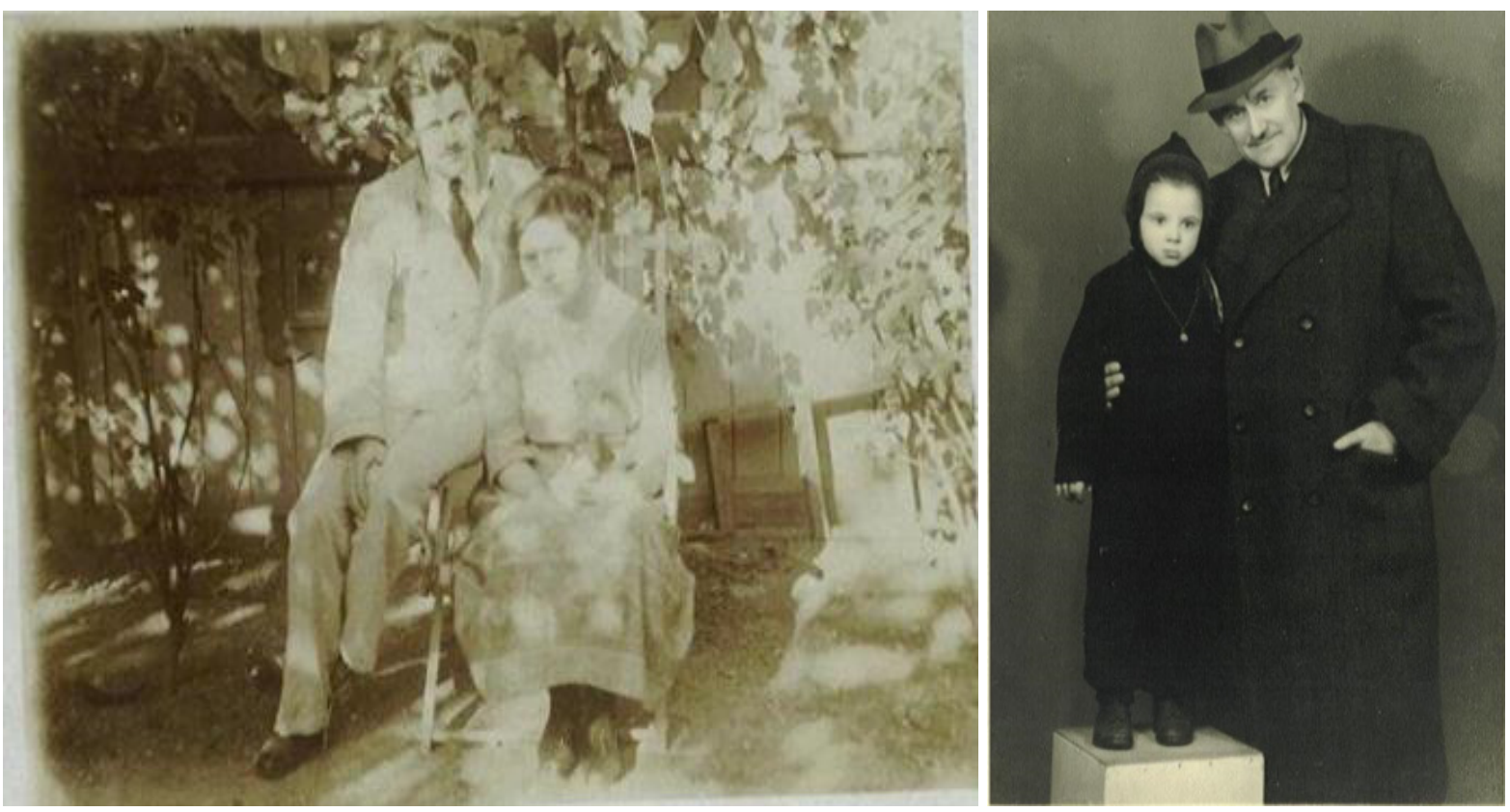

1-2. kép: Mesteházy Jenő, férj és apa 
Mesterházy Jenő életében fontos szerepet töltött be a családja, a hagyaték képi és írásos emlékeiből is erre következtethetünk. Feleségéhez, Baló Judithoz mély szeretet kötötte, közös képeikről is sugárzik, valamint azokból a levelekből, képeslapokból, amelyeket férje neki címzett a külön eltöltött időszakokban (például I. világháború, később pedig a különböző kirándulások alkalma - Bécs). Egy gyermekük született, aki édesanyja után kapta keresztnevét - Mesterházy Judit. A képeken és említésekkor is Jutkaként olvashatunk róla. A fentebb látható mütermi kép tanúsága szerint a kislány születésekor már szülei idősebbek voltak, talán ennek is betudható, hogy nem vállaltak több gyermeket. Sok információt nem tudunk meg egyébként a gyerekről, még a születési adatait sem ismertük meg.

\section{Családi portré}

A Mesterházy-hagyatékban találhatók családi képek, amelyeken a családfö feleségével található, valamint lányával készült közös képek is akadnak. Éppen ezért érdemes kicsit elmélyülni abban, milyen szokások jellemzik a családi portrékészítést.

Az ilyen képek fontos célja, hogy a családot mint szervezett egységet fenntartsák az utókor számára is. A nyugati kultúrában általában az apa személye szellemiséget tükröző, az anya pedig az érzelmeket sugárzó egyén a képeken. Ezek persze átfedéseket és felcserélődéseket is mutathatnak.

A családi portrékon belül kétféle típust különböztethetünk meg Julia Hirsch említése szerint (Hirsch, 2000), így a beállitott képeket, valamint a pillanatfelvételeket. A beállított képekre jellemző, hogy a rajta lévő személyek stabil, méltóságteljes pozíciót vesznek fel, általában szembe néznek a kép nézőjével, az egész kompozíció statikusnak tekinthető.

Legfőbb témája az ilyen képeknek a jellem bemutatása, az érzelmek kevéssé játszanak szerepet. Ezzel szemben a pillanatfelvételek a véletlen mozdulatokat helyezik előtérbe, amelyek által a kép nézői számára megpróbálja közelebb hozni az egyén valódi személyiségét. Ezen inkább megjelennek valós, emberi érzelmek, életközelibb helyzetek. Az előbbi portrékészítés jelszavának az „üljön egyenesen!" tekinthető, míg utóbbinál az „engedd el magad!" a fö instrukció.

A kép helyszínéül nem túl gyakori választás volt a mütermi fotókészítés, amely a realitásoktól való időleges mentességet is biztosított, hiszen bármilyen háttér elé állhattak a kép szereplői, így a különbözőségek áthidalhatóvá váltak és bensőségességet is teremtettek. Ezek a képek uniformizáltságot tükröznek, valamint a képeken szereplők személyiségét és közöttük lévő emberi viszonylatokat helyezik a középpontba. Érdemes lehet a vizsgálatra a kéz vonala, tekintet iránya, illetve a szájszöglet is. A tekintetre vonatkozóan kiemelhető, hogy a direkt kamerába nézés mellőzött volt a „buta” illetve fájdalmas arckifejezés miatt.

A gyerekek ezeken a műtermi, beállított képeken kifejezetten koravénnek tűnnek, főképpen a felnőttes pozíció miatt, amelybe állítva vannak. Ez látható Mesterházy Jutka esetében is, akinek mind az arckifejezése, mind az öltözete felnőttessé teszi őt.

A legkedveltebb családi képtípusnak tekinthető a szülők és gyerekek együttes ábrázolása.

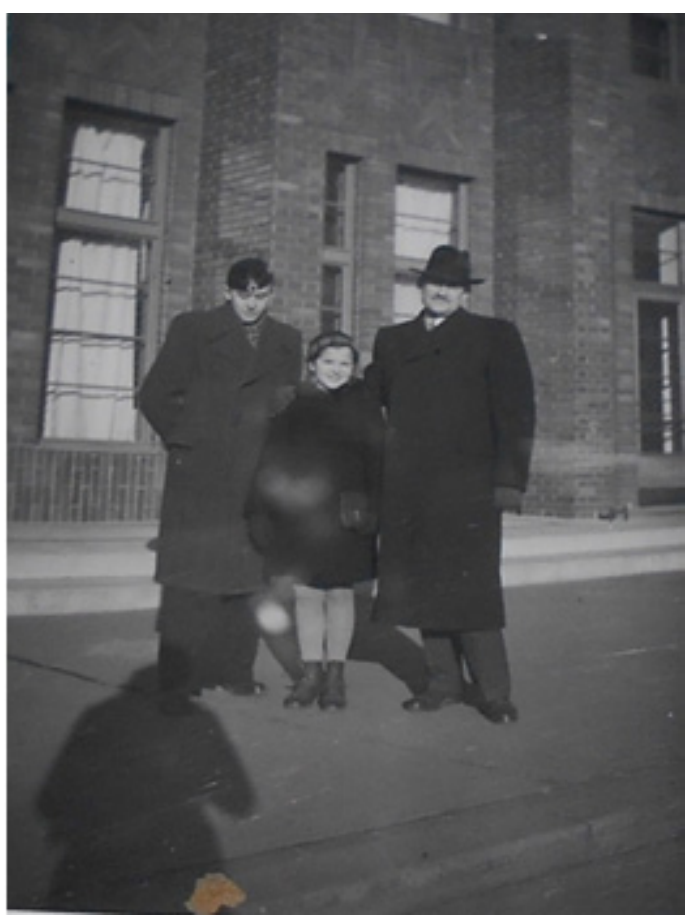

3. kép: Apa és lánya 
Ezen a képen is látható az apa és lánya, valamint egy fiatalabb fiú is, akiről nem lehet tudni biztosan, hogy családtag-e. A képen egy felszabadult kislányt láthatunk, nem pedig mereven beállítottat, mint a mütermi kép esetében. A fénykép készítője elképzelhető, hogy az édesanya, azaz Judit volt, de egészen biztosan ezt sem tudhatjuk. Nappal szembe állították be a kép szereplőit, valamint a készítő teljes árnyéka is a képben van. Gondolhatjuk ebből, hogy gyakorlatlan volt, aki fotózta, hiszen nem szerencsés beállításnak tekinthető ez a kép minőségét tekintve (belógó alak).

\section{Közös kirándulások}
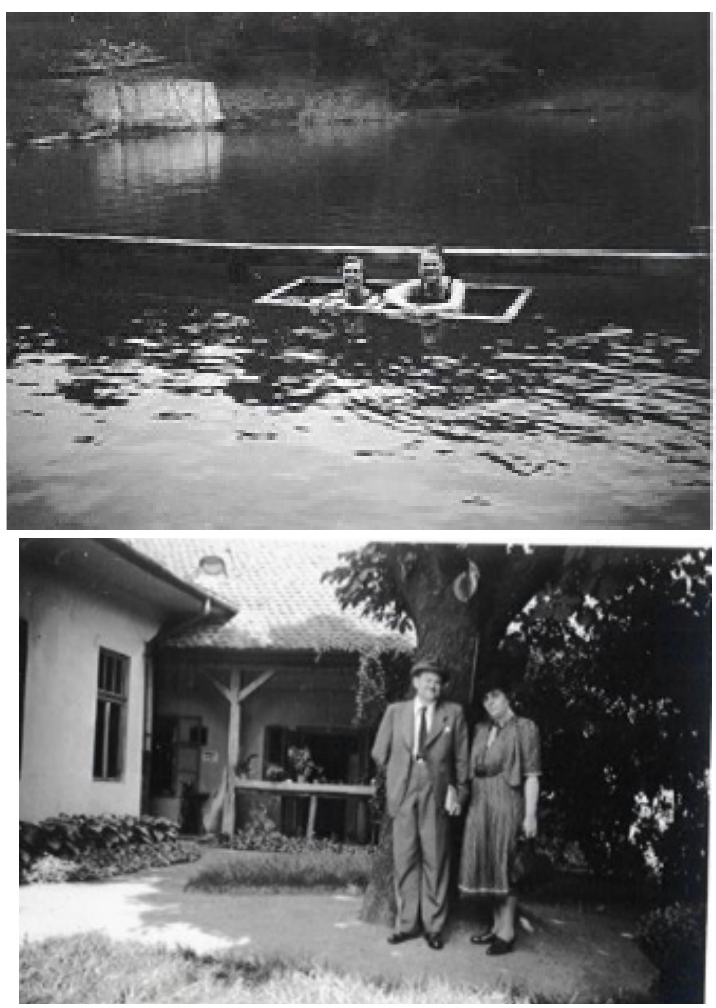

4-5. kép: Kirándulások

A házaspár életében minden bizonnyal fontos volt a közös kikapcsolódás, közös élmények és együtt eltöltött idő. Ebből is arra gondolhatunk, hogy nagy szeretetben éltek és szívesen voltak egymás társaságában még idősebb korukban is. A bal oldali kép Kolozsfürdőn készült, ahova valószínüleg nyaralni mentek el. A mellette lévő kép pedig Kolozsvár, a kép hátuljára írt információ szerint, ami elképzelhető, hogy a szálláshelyüket ábrázolja. A képeken közel helyezkednek el egymáshoz, testük több helyen is érintkezik (pl. egymás kezét fogják, összeér a karjuk). Ezekből az apró non-verbális jelekből sejthető a köztünk lévő kapocs erőssége, az összetartozás. Az életrajzából megtudható, hogy az 1940-ben visszacsatolt észak-erdélyi területek megismerése céljából kultúresteket rendeztek a tanítóképzőben, amelyen maga Mesterházy is előadást tartott. Elképzelhető, hogy érdeklődése is kötötte őt Erdélyhez ennek kapcsán is választották ezt az úti célt. Nem tudni, hogy pontosan mikor készültek ezek a képek, de az látható, hogy már mindketten idősebb korúak ez időtájban.
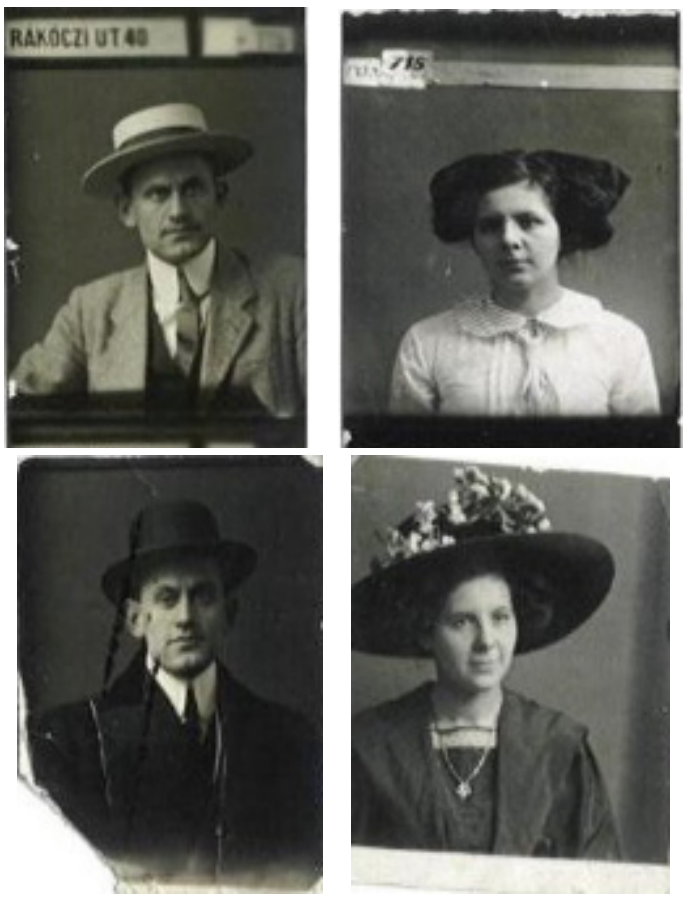

6-9. kép: Férj és feleség

\section{A pedagógus - hivatásának gyakorlója}

Meglepő módon viszonylag kevés képi emlék lelhető fel a hivatásával kapcsolatos tevékenységei közül. Ez egyrészt fakadhat abból, hogy ugyan megőrzésre kerültek, de valami oknál fogva elkallódtak az évek során. Másrészről pedig abból, hogy maga Mesterházy kevéssé tartotta megörökítésre valónak a mindennapi munkát, amiben élt és dolgozott, így nem került rá nagyobb hangsúly és intézményi szinten sem tartották ezt lényegesnek. Ennek fényében nem volt nehéz dolgunk válogatni azon képek közül, amelyeket szakmai szempontból bocsájthatunk elemzésre. 


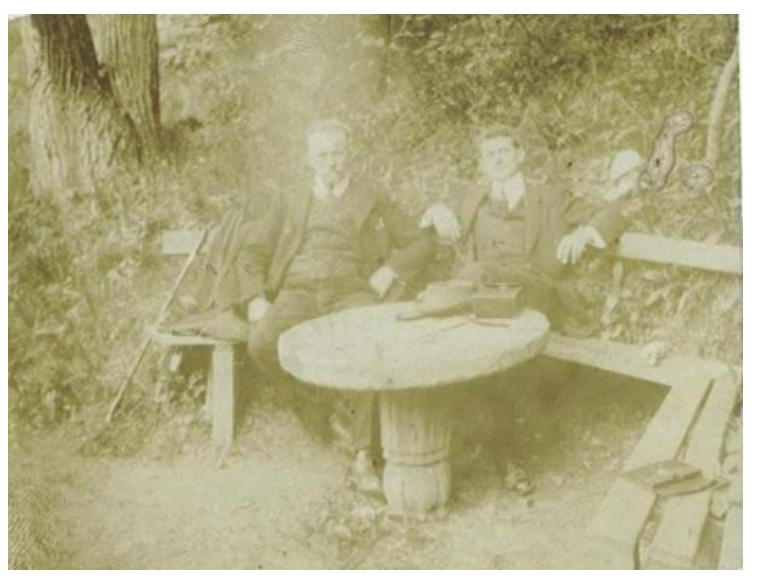

10. kép: Az ifjú Mesterházy

Ezen a képen az ijfú Mesterházyt láthatjuk, amint egy idősebb úr mellett foglal helyet valamilyen erdei környezetben. Nem derül ki, hogy éppen mi történik vagy miért gondolták megörökítésre méltónak ezt a pillanatot, de számunkra azért fontos, hiszen a kép hátulján olvashatjuk, hogy 1913/14-ben készült Modoron. Az életrajzi adatokból tudhatjuk, hogy 1913-ban kapott segédtanári kinevezést Modoron, tehát a képen nagy valószínüséggel ezt az időszakot láthatjuk. A mellette helyet foglaló idősebb személy elképzelhető, hogy egy tanár úr, aki a pályakezdő ifjút terelgette munkájában. Talán egy séta alkalmával készült ez a kép az éppen megpihenő idősebb tanárról és a segédtanár Mesterházyról (mesterről és tanítványáról?). Érdekes a két személy testtartásának különbségeit szemügyre venni. A fiatalosság, laza testtartás és mellette kontrasztosan a már merevebb tartás, komolyabb ábrázat, tekintélyparancsoló küllem. Nem maradt fent több emlék e kezdő időszakából sem, így fontos képi emlékként tekinthetünk erre.
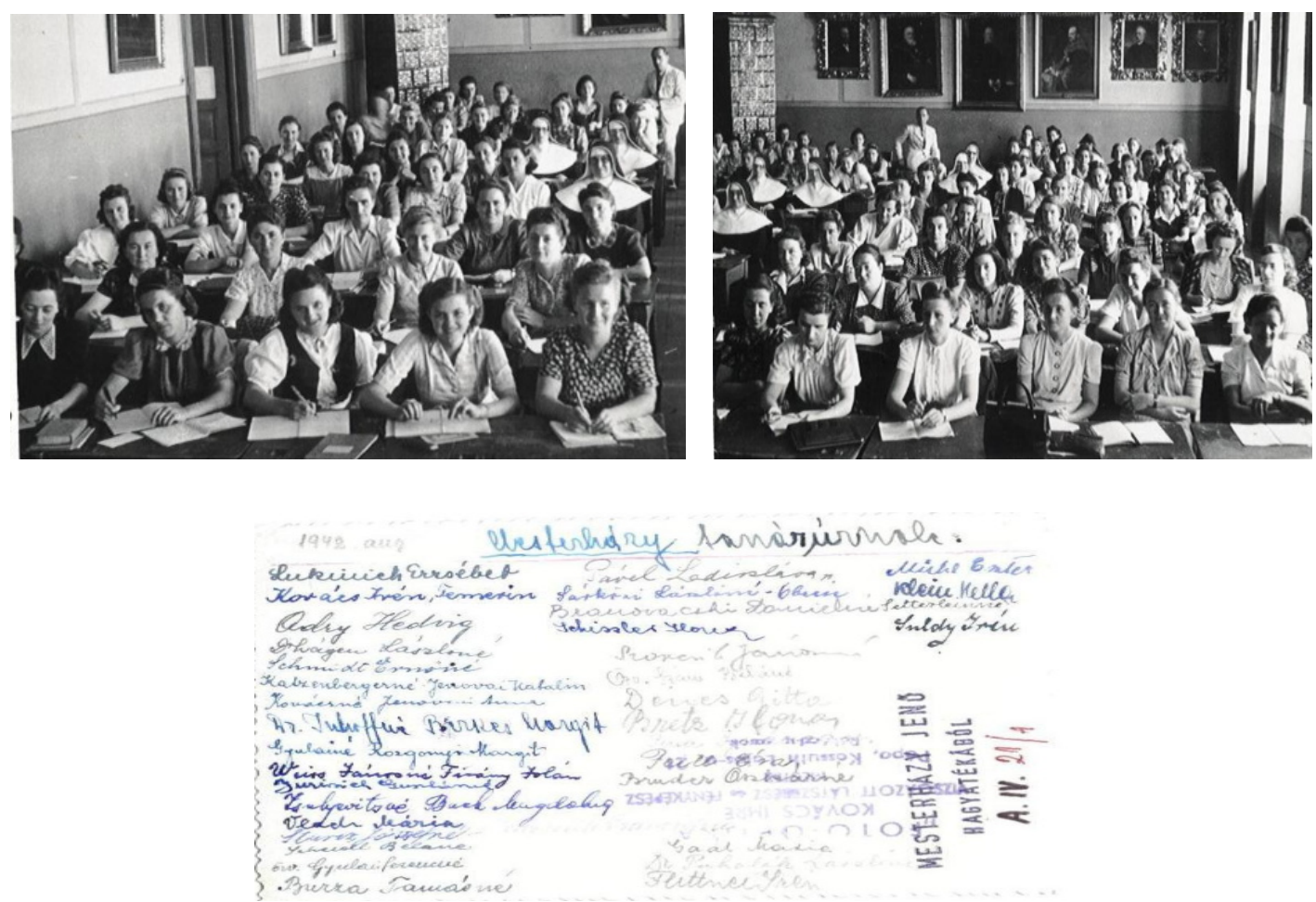

11-13. kép: A leendő pedagógusok 
Az életrajzi adatokból ismeretes, hogy 1940-ben az Esztergomi Tanítói Továbbképző Tanfolyamát végezte el. Ezzel kapcsolatos a fentebbi három kép 1942-ből, amelyeken éppen egy továbbképzést láthatunk megörökítve. A képen szereplő nők valószínűleg tanítónők voltak, akik továbbképzésre érkeztek Mesterházy Tanár Úrhoz. Nem derül ki, hogy pontosan hol készültek ezek a fényképek, de elképzelhető, hogy valamelyik tanítónőképző intézetben. A fényképek hátulján olvashatók a jelenlévők aláírásai amit „Mesterházy tanár úrnak” írtak össze. Ebből következtethetünk arra, hogy mély benyomást tett a hölgyekre, hiszen ezért tarthatták fontosnak, hogy aláírják neki a képeket, amiken szerepelnek. Akár kérhette maga Mesterházy is ezt tőlük, hogy emlékként megőrizze. Az viszont mindenképpen leszürhető, hogy fontos szerepet tölthettek be az ő életében a különböző továbbképző tanfolyamai. A képen láthatunk apácákat is, amiről arra következtethetünk, hogy mind világi mind egyházi tanítónők is részt vettek ezeken a tanfolyamokon.

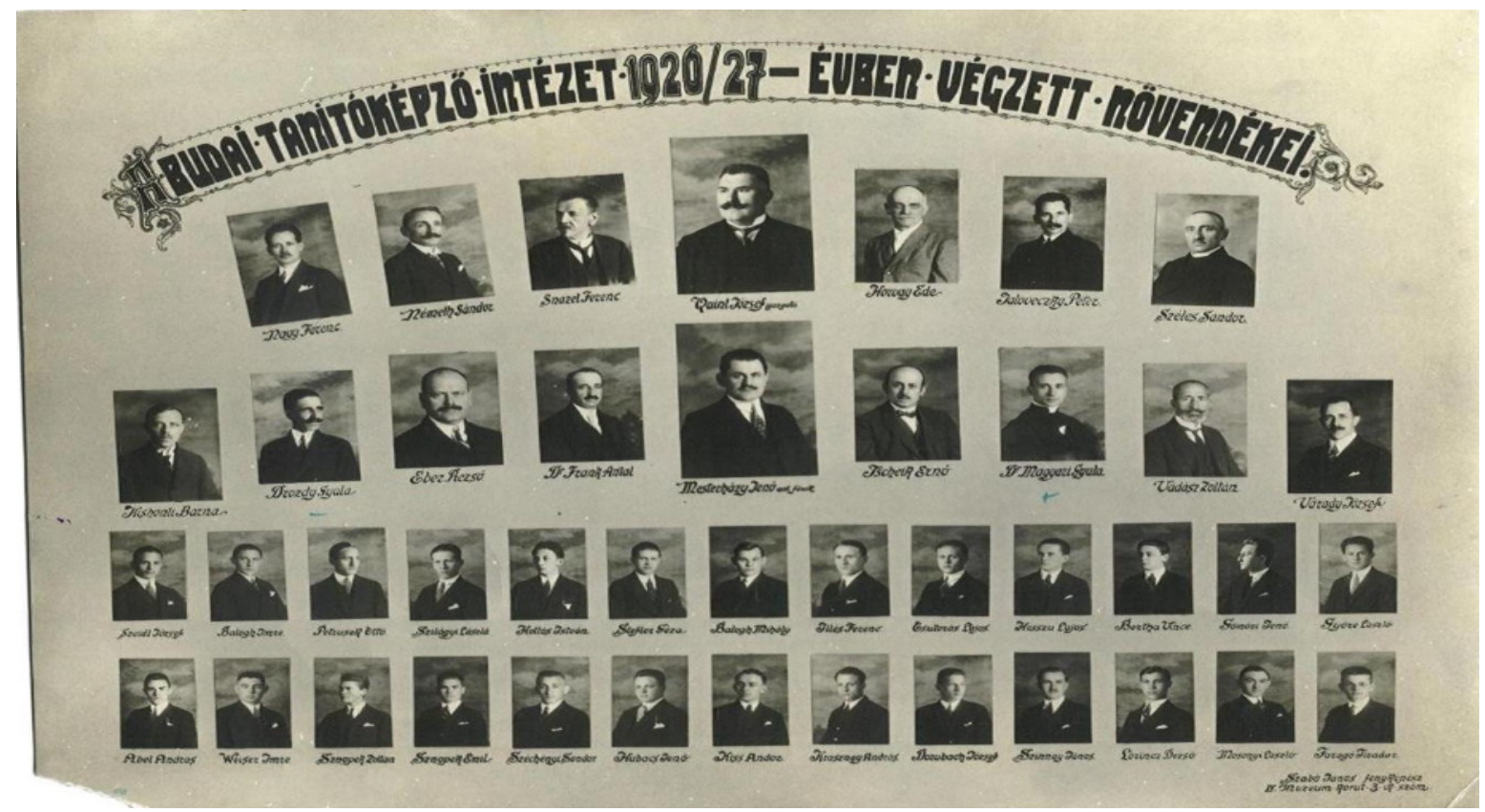

14. kép: Tablóképen

Egy formálisabb emlékkel zárul a hivatásával kapcsolatos fotóemlékek áttekintése. Itt Mesterházy Jenőt mint osztályfőnököt láthatjuk az 1926/27-ben végzett tanító növendékei között. Ebben az időszakban csak férfiak jártak a Budai Tanítóképzőbe, valamint a tanári kar is kizárólag férfiakból állt. Érdekes összevetni a későbbi tanfolyamon készült képek- kel, ahol már kizárólag csak nők vettek részt. A szakmai életrajzából ismeretes, hogy történelem, magyar és földrajz szakos, tornatanári oklevéllel rendelkező tanár volt.

Az egyesületi élet is fontos volt számára - T.I.T.O.E értekezlet a Damjanich utcai tanítónőképzőben 
Képekben elbeszélt múlt - Mesterházy Jenő

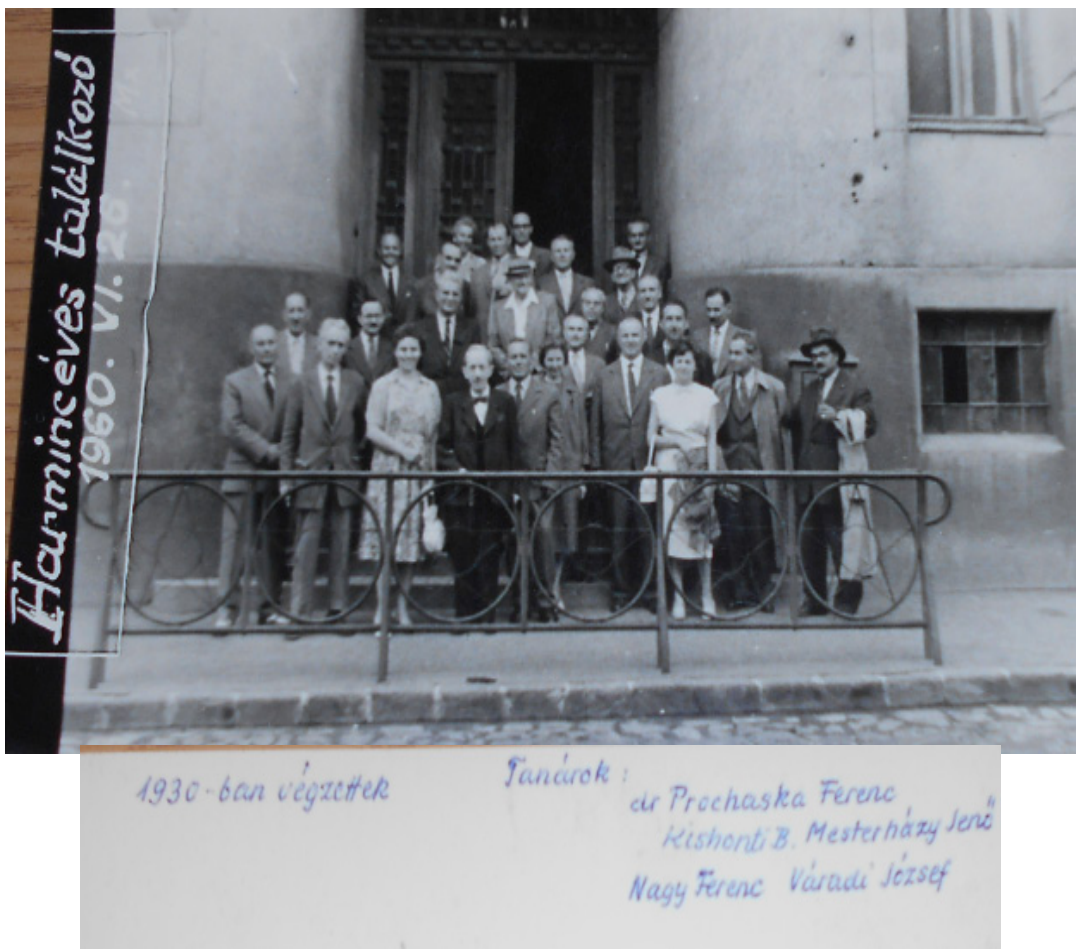

15. kép: Harmincéves találkozó

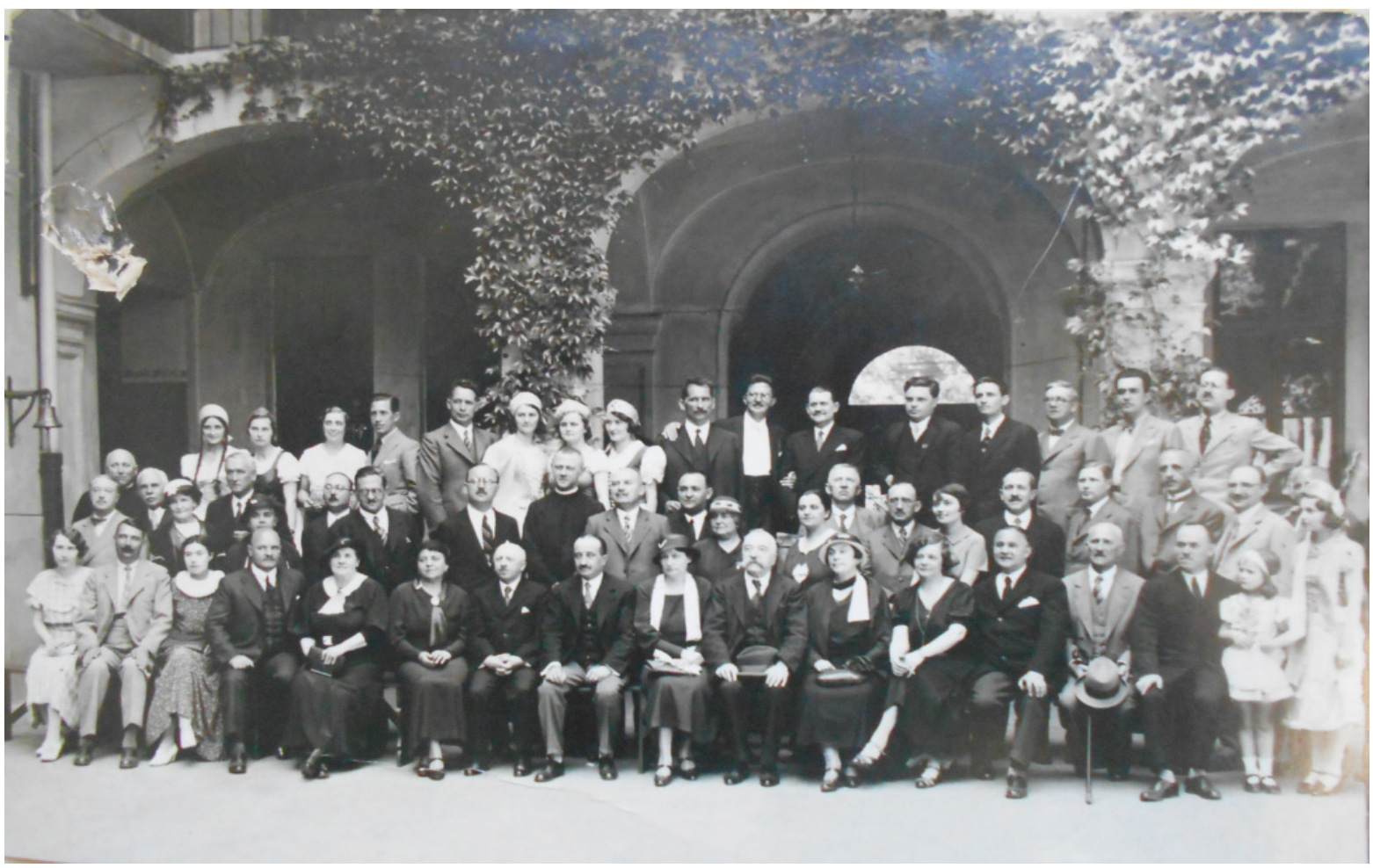

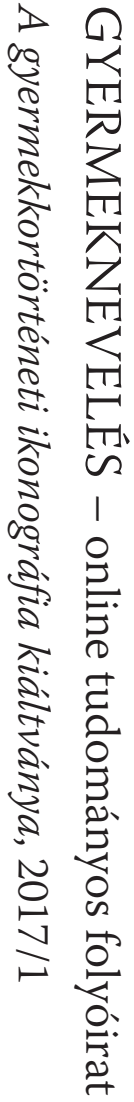

16. kép: Az egyesületi élet is fontos volt számára -

T.I.T.O.E értekezlet a Damjanich utcai tanítónőképzőben 


\section{Iskolán kívüli élet - a cserkészet}

A Tanítóképző 1927-ben életre hívta az Apáczai cserkészcsapatot, amivel kapcsolatban a hagyaték képi emlékeket is tartalmaz. Mesterházy a szívén viselhette ezt az iskolán kívüli tevékenységét is, valamint fontosnak érezhette a tábori élet dokumentálását.

Ezt abból sejthetjük, hogy a megérkezés pillanatától számítva a reggeli gyülekezőn át a tornáig és az ebéd megfözéséig minden eseményről készült kép. Nem tudjuk pontosan, hogy ő készítette-e őket, de vélelmezhető, mert csak egy csoportképen szerepel, így gondolhatjuk, hogy a képeket ő készítette.

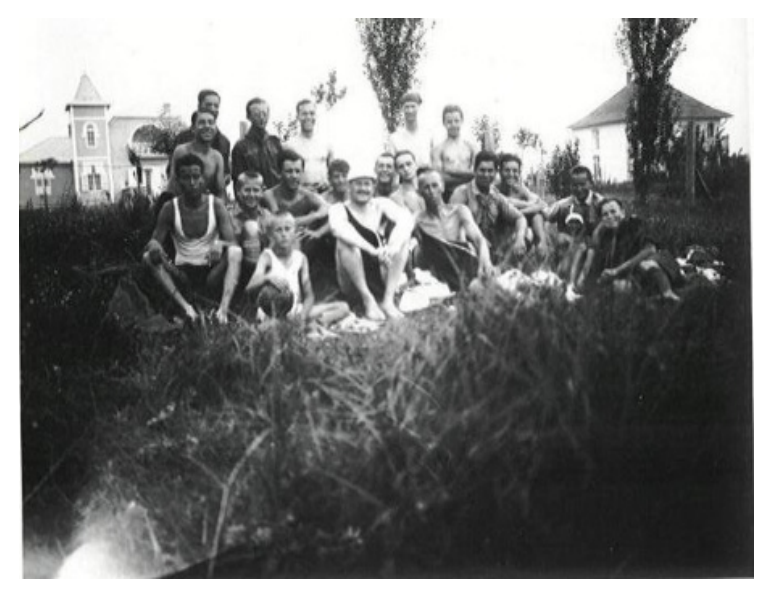

17. kép: Cserkészetben

Ezen a képen a táborozó gyerekek között láthatjuk a Tanár Urat. A fényképet önkioldóval készíthette, amit a földre helyezett le, hogy mindenki benne lehessen a képben. Ezt valami miatt fontosnak érezhették, ezért sem úgy készülhetett, hogy egyikük lefényképezte a csapatot. Mindenféle korú fiúkat láthatunk a csoport tagjai között. A fotó helyszíne ismeretlen, valahova kirándulhattak és ott álltak össze egy csoportképre. Valószínűleg nyár lehet, láthatjuk ezt például könnyed öltözetükből, valamint a növényzetből is erre következtethetünk. Néhány idősebb fiún cserkész egyenruha látható, elképzelhető, hogy nekik magasabb beosztásuk volt a táborban és ezért viselték egy szabadabb kirándulás alkalmával is.

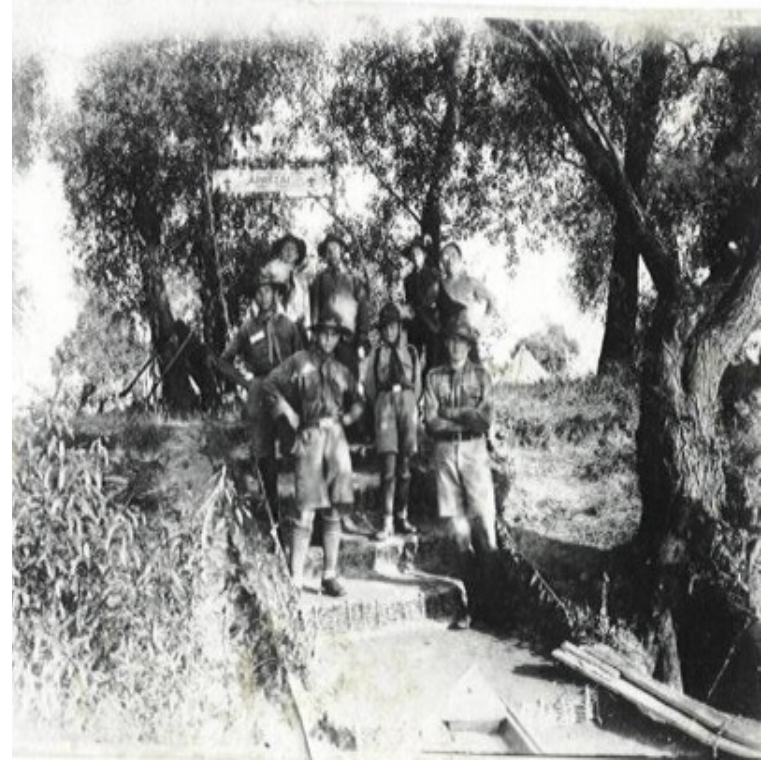

18. kép: Cserkészcsapattal

Ez a kép is a csapatot ábrázolja, valamivel formálisabb helyzetben, hiszen mindegyik ifjú egyenruhát visel. A háttérben olvasható az „Apáczai” felirat, amiből sejthető, hogy a tanítóképző által alapított cserkészcsapatot láthatjuk megjelenni ezeken a képeken. Ennek a hátulján találhatunk feliratot is, amelyből megtudhatjuk a képek készítésének időpontját. 1932-ben készültek, ez a csoportkép pedig egészen pontosan a Kácsa-szigeten (fokozottan védett terület a Holt-Tiszán). A háttérben egy sátor található, ami arra enged következtetni, hogy ez a kép a táborhelyen készülhetett, vagyis a Kácsa-szigeten töltötték el az időt a cserkészgyerekek és Mesterházy Jenő.

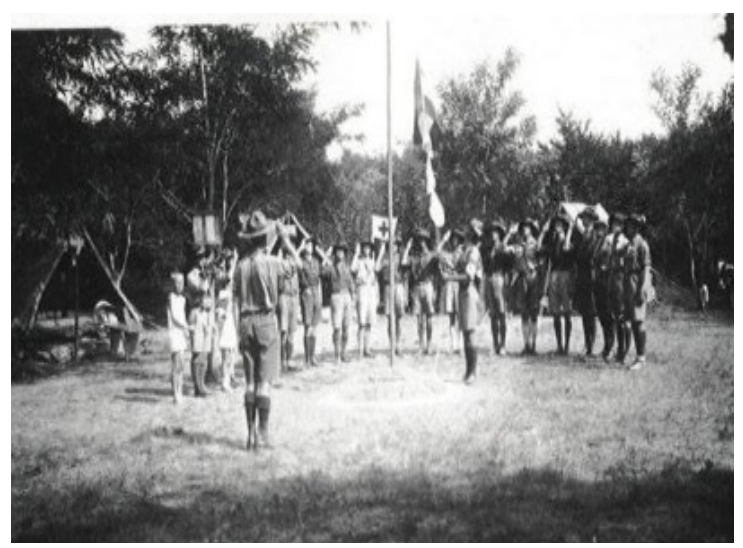

19. kép: Zászlófelvonás

A tábor alakulóterén a zászlófelvonást láthatjuk, valamint az azt kísérő tisztelgést. Az 
egész cserkészcsapat jelen van, két kisebb gyerek kivételével mindenki egyenruhát visel. Róluk nem lehet pontosan eldönteni, hogy kihez tartoznak, illetve miért vannak jelen a táborban. A háttérben egy zászlót is láthatunk, ami fehér alapon valószínűleg egy piros keresztet ábrázol. Sejthető, hogy Mesterházy készítette a képet, hiszen ő nincs jelen a fotón, valamint a gyerekek közül mindenki az eseményre koncentrál.

\section{A népművelés zászlóvivője}

Mesterházy Jenő népművelő munkássága mindenképpen kiemelendő az életútját figyelembe véve, hiszen a képek tanúsága szerint iskolán kívüli tevékenységként sok ismeretszerző, helyismereti kirándulást vezetett. 1933-ban ezért bronz emlékérmet kapott a népművelés terén kifejtett érdemes és önzetlen munkájáért a Budapest Székesfőváros Iskolánvkívüli Népművelési Bizottságtól. Emiatt fontosnak véljük, hogy pár képi hagyatékkal is illusztráljuk mindezt és emlékezzünk meg e fontos tevékenységéről.

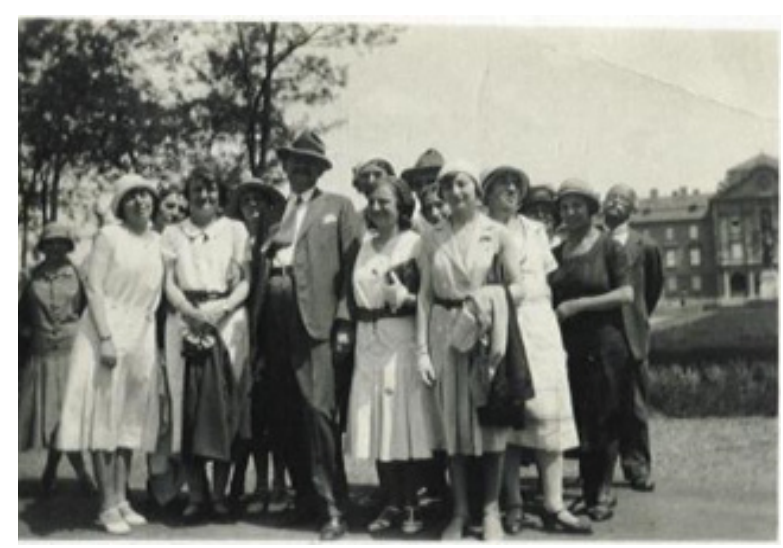

20. kép: Hölgykoszorúban

Ezen a fotón egy csoportképet látunk, ahol hölgykoszorú veszi körbe Mesterházyt. Rajta kívül két férfi látható még a képen, arról nincs információ, ki készítette a képet. A környezet egy udvarszerü résznek, parknak látszik, ami a háttérben lévő épülethez tartozik. Az öltözetekből kiindulva jó idő lehetett, a növényzetet látva is sejthető a tavaszinyári évszak. Egy kiránduláson lehetett a társaság, amely végén a jelenlévők összeálltak egy közös fényképre. A kép hátulján annyi információ található, hogy „1932. Gödöllo”, amiből kiderül, hogy valószínűleg a gödöllői kastély parkiában áll a csoport. A kép készítésének apropója valószínűleg az volt, hogy megörökítsék ezt a kirándulást és az ott jelen lévő személyeket is. Mesterházyn kívül nem tudni, hogy kik vannak a fotón és a foglalkozásuk is ismeretlen. Lehet, hogy tanítónők voltak, de az sem kizárt, hogy „civil” érdeklődők. Ez egy beállított képnek tekinthető, hiszen direkt úgy és azért álltak össze, hogy elkészülhessen. A korból adódóan fekete-fehér a fotó, a fények eséséből láthatóan napsütés volt (némely arc sötétebb, árnyék vetül a kalaptól rá). A nők öltözete a '30-as évek divatjának megfelelő, egyszerü viseletet mutat. Már eltűnőben volt a földet súroló hosszú szoknya, helyette a könnyedebb, kényelmesebb viselet jött divatba. Világos színű, harang alakú szoknyás egyberuhát visel a legtöbbjük. Mesterházy öltönyt visel, élén vasalt nadrággal és szépen hajtogatott zsebkendőt a zsebében és nyakkendőt. Kalapot vagy kendőt szinte mindenki visel a fején. A kép középpontjába egyértelműen a kirándulást vezetőjét, Mesterházy Jenőt helyezték, aki büszkén kihúzza magát. A kép lényege a személyek megörökítése volt, így a háttér nem kap nagy jelentőséget.

Ez a kép szintén Mesterházy népművelő tevékenységéhez tartozik, hiszen ez is egy kirándulás alkalmával készült fénykép. Egy emlékműnél állt össze a csoport szintén egy közös képre. Itt vegyesen vannak nők és férfiak is jelen, az öltözékükből pedig az a következtetés vonható le, hogy jobb módúak vettek részt rajta, mint a fentebb említett gödöllői kastélylátogatáson, de az is helytálló lehet, hogy egyszerűen a rosszabb időjárás miatt öltöztek fel alaposabban. Ez a kép képeslapként lett előhívva, mégpedig abból a célból, hogy feleségének elküldhesse. Ebből tudhatjuk meg, hogy a kép 1937. szeptember 5-én készült Bécsben. Kis utánajárás után azt is tudni lehet, hogy a Volksgardenben ülnek a kép szereplői Erzsébet királyné szobra alatt. Szintén beállított képről beszélhetünk, a készítője valószínűleg guggolt a fotózáskor, így sikerült 


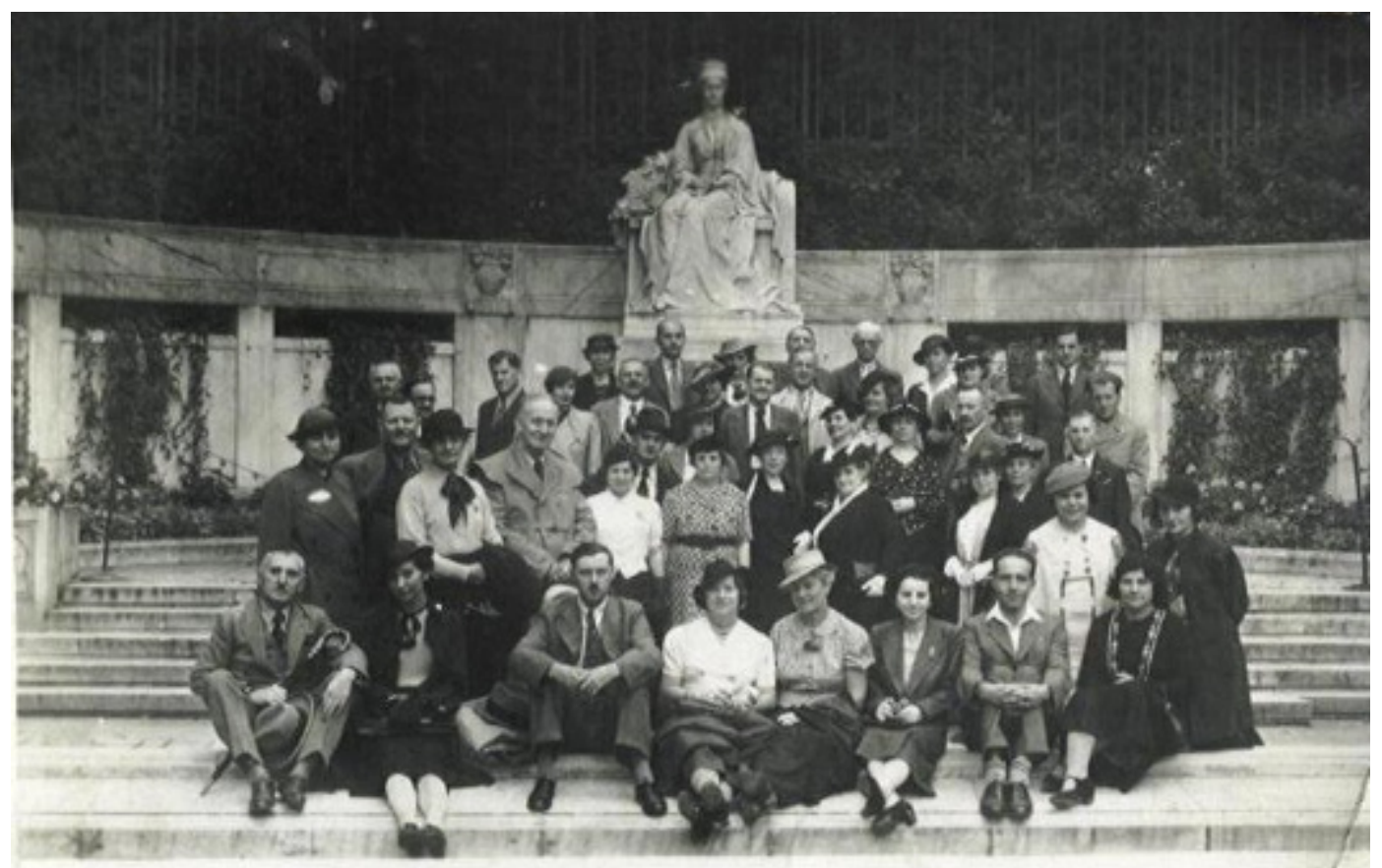

21. kép: Bécsben

a szobornak is beleférnie a képbe, valamint olyan hatású az egész, mintha az emlékmü hatalmas lenne az emberekhez viszonyítva.

A másik fotó esetében a csoporton volt a hangsúly, itt viszont maga a helyszín megörökítése is szempont lehetett a csoport és a fotós teljesen, bár középen helyezkedik el. Az öltözetükből és az úti célból is levonható követ-

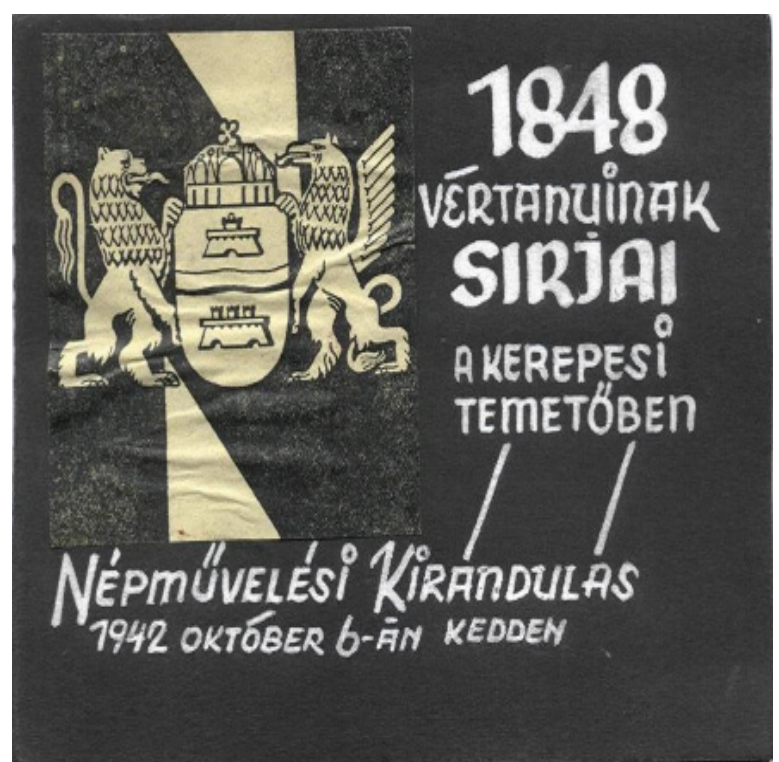

keztetés, hogy jobb módú személyek vettek részt a kiránduláson. A nőknél felfedezhető kiegészítők a gyöngysor nyakék, bross a ruhára tűzve, sál a nyakban, kalapok, kesztyűk, kézitáskák. Ruházatot tekintve kosztüm a legelterjedtebb viselet, amelyet egyesek kabáttal kiegészítve viseltek. Férfiak öltönyt viselnek, némelyek mellénnyel kiegészítve. Az időjárás valószínű ősznek megfelelő volt, mind a ruházat, mind pedig az esernyőből kiindulva.

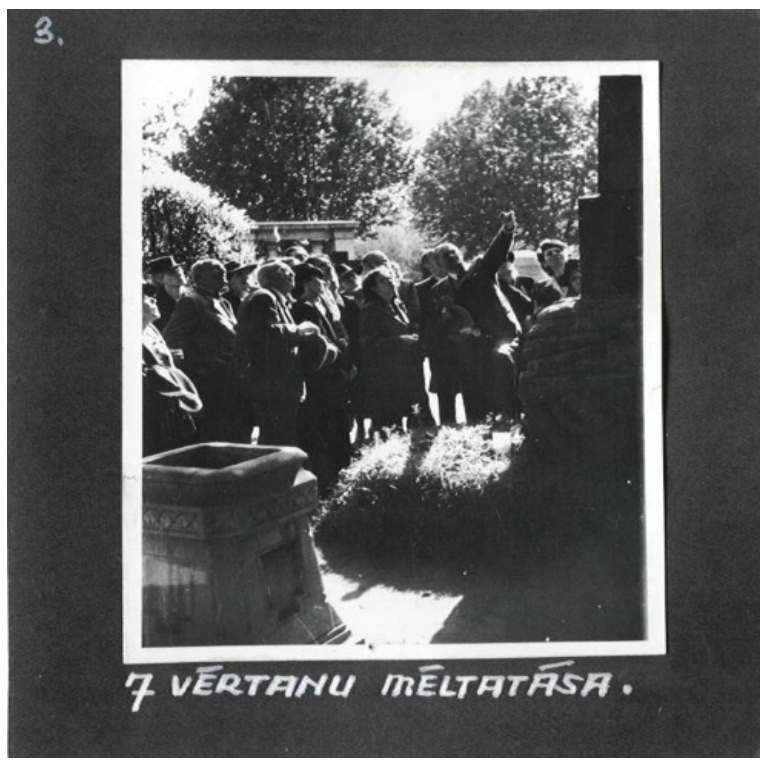

22-23. kép: "Vértanúkkal" 
Ehhez a képsorozathoz egy album is tartozik, amelyben sorba rendezve lettek összegyüjtve a képek. Ebből pontosan megtudhatjuk mi célból, hol és mikor történtek az események. Mesterházyt a második képen éppen „munka közben” láthatjuk, ahogy az érdeklődo sokaságnak mutatja az aradi vértanúk síremlékét. Kérdéses az, hogy a fotós vajon öncélúan készítette-e a képeket abból a szögből és akkor, amikor akarta vagy az volt a kérés felé, hogy örökítse meg pillanatfelvételekként a kirándulást (életképekként). Itt is napsütéses idő lehetett a fényekből láthatóan. A kirándulás résztvevői mindenféle korosztályból kerültek ki, egyaránt nők és férfiak. Az elhelyezkedésükből és a tekintetekből az érdeklődés vonható le következtetésképpen. Ez a sorozat valamilyen későbbi felhasználásra készülhetett, hiszen a korábbiaktól eltérő módon albumba vannak rendezve, sorszámmal, címmel ellátva.

Mesterházy Jenő Budapest egyes temetőit is megörökítette publikációiban, népművelői tevékenységéhez is hozzákapcsolta azok látogatását, hiszen például katonai mivoltából adódóan, akár a világháborúkban elesettek előtti tisztelgés, megemlékezés szempontjából is fontosnak tarthatta e helyszíneket ${ }^{5}$.

\section{A katonaférfi}

Mesterházy Jenő életét a két világháború is feldúlta. Az I. világháborúban 26 éves, éppen csak pályáját megkezdő ifjúként vett részt, a II. világháború 51 évesen érte, ahol mindöszsze háromhónapnyi katonai szolgálatot töltött el az életrajzi adatok szerint. Az I. világháborúban katonai szolgálatot teljesített 1914. augusztus 2-től 1918. novemberig, ebből az időből 39 hónapot a harctéren. Fényképekben nagyon gazdagon dokumentált az 1914-1918 között eltöltött katonai élete, ami nagyban betudható annak, hogy feleségének szerette volna megmutatni, hol van és mi történik vele. Ezt onnan tudhatjuk, hogy sok kép hátuljára leírta a helyszínt és a történéseket, valamint

\footnotetext{
5 lásd: http://www.bparchiv.hu/id-661-budai_temetok_ valogatott_bibliografiaja.html
}

a képeket képeslapként címezte feleségének, akivel ekkor még éppen csak házasok voltak. Itt fontos megemlíteni, hogy a háború borzalmairól ezek a képek nem tudósítanak, de a hagyatékban fellelhetők olyan, valószínűleg Mesterházy által készített fotók is, amelyek a háború szörnyűségeiről tanúskodnak (például egy ismeretlen férfi kivégzéséről fotósorozat).

Feleségén kívül édesanyjának is küldött képeket, amelyek hátuljára pár szeretetteljes szót is írt.
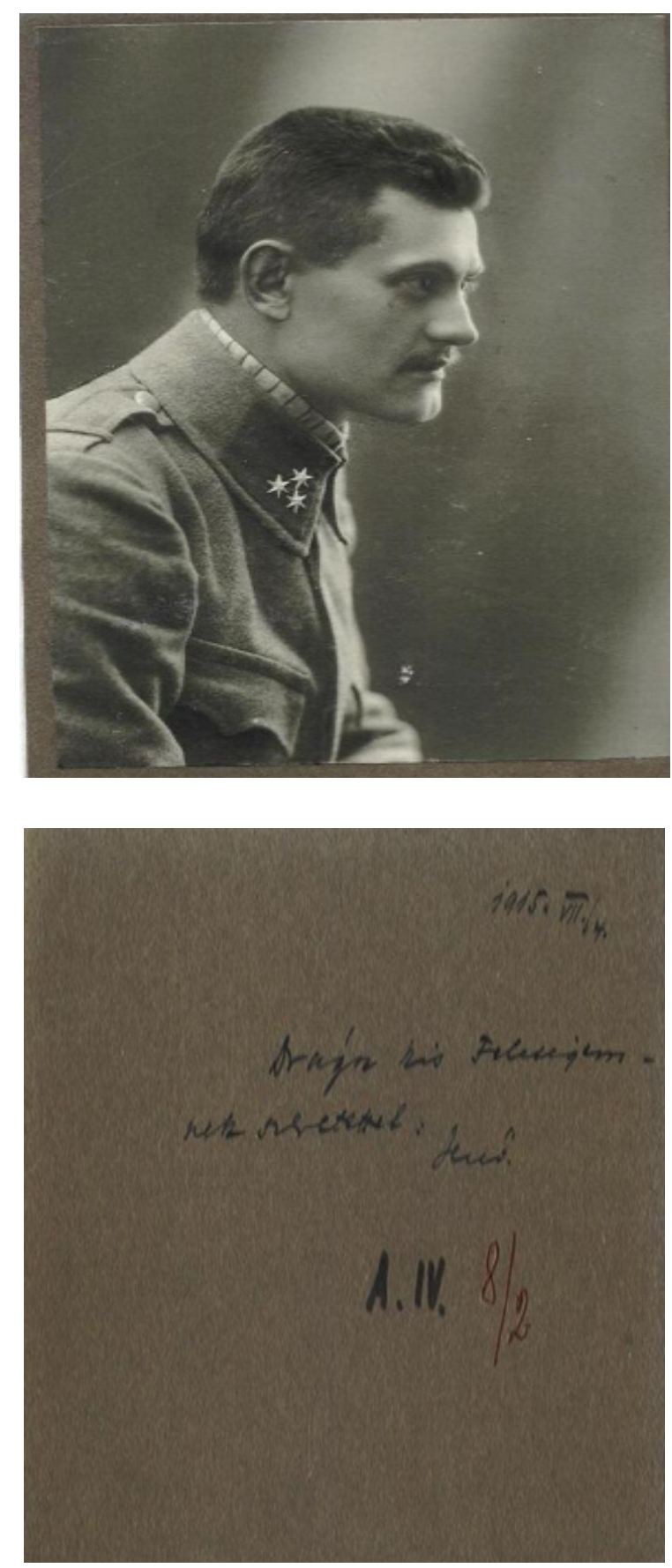

24-25. kép: Katonasors 
1915. július 4-én küldte feleségének ezt a hogy minden katonáról készítettek egy ilyen képet, amely már a fronton készülhetett róla (az egyenruháján lévő jelvényekből kiindulva, szakaszvezető tisztséget töltött be). Egy kemény lapra van felragasztva a fotó, ami arra utalhat, hogy fontosnak tartotta és szerette is volna, hogyha felesége őrzi és esetleg magánál is tartja ezt a képet. Abszolút beállított fotót még a bevonulásuk idején, amit hazaküldhetett a családnak. Nem is találni több ilyet a hagyatékban, mert azok inkább pillanatképek, amelyek az eseményeket és a személyeket hívatták megörökíteni. Nem tűnik megviseltnek a kép szereplője, ebből is arra ez a kép, amire az engedtet következtetni, nulás után készülhetett róla ez a portréfotó.
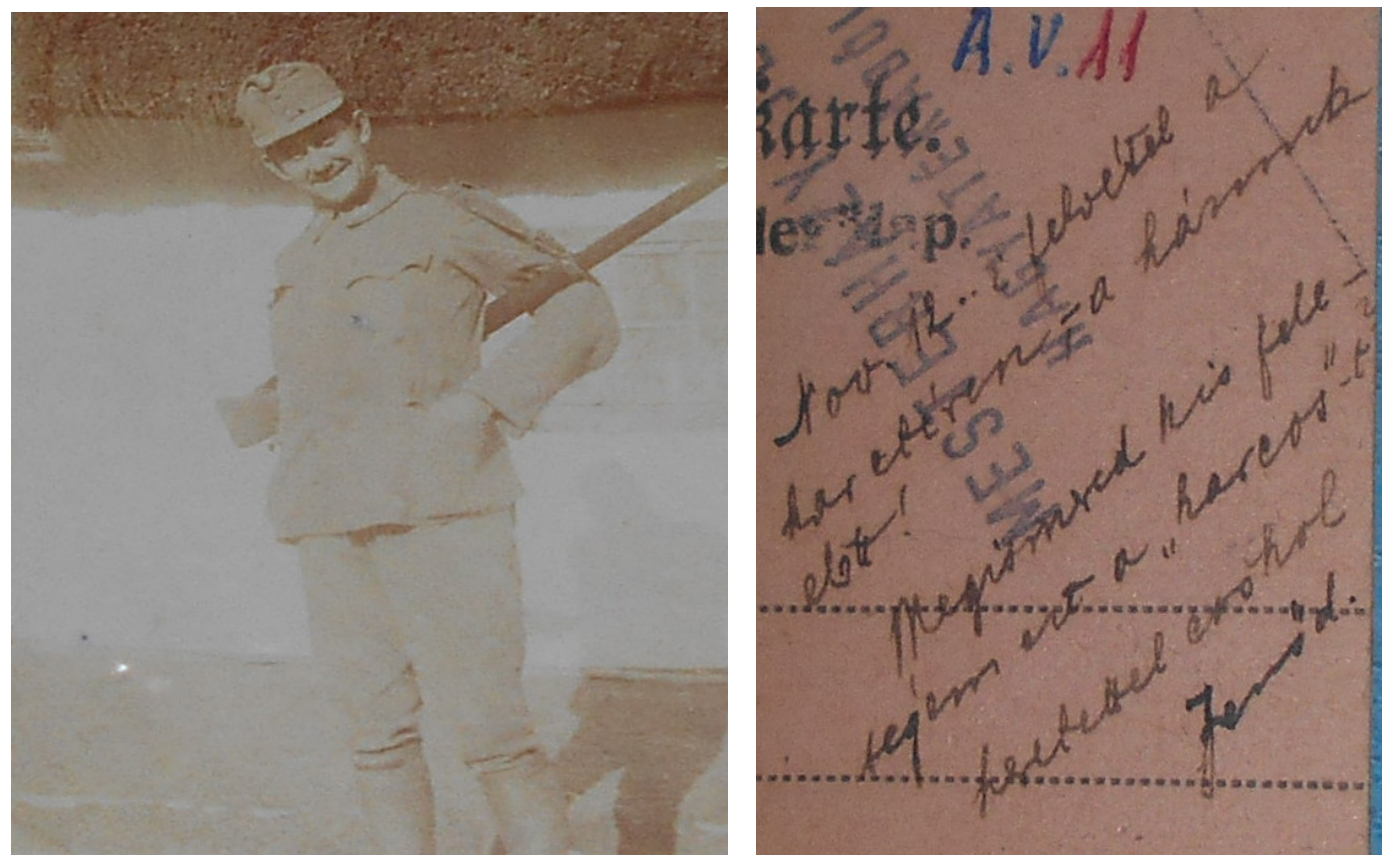

26-27. kép: Feleségének

Az elöbbinél sokkal oldottabb ez a kép, amelyet szintén feleségének szánt november 12-ei dátummal. Azt is megtudhatjuk, hogy a kép a harctéren készült a házuk előtt, az árnyékból ítélve, szép napos időben. Derü sugárzik erről a képről és a leírásból is ez érződik, aholis „harcosként” nevezi meg magát és kérdezi feleségét megismeri-e őt eképpen. Fontosnak érezhette, hogy megossza vele ezeket az élményeit és ezért is szerepelhet sok fotón. Nem lehet tudni ki készítette a fényképet és azt sem, hogy egyáltalán hogyan került fényképezőgép a táborukba.
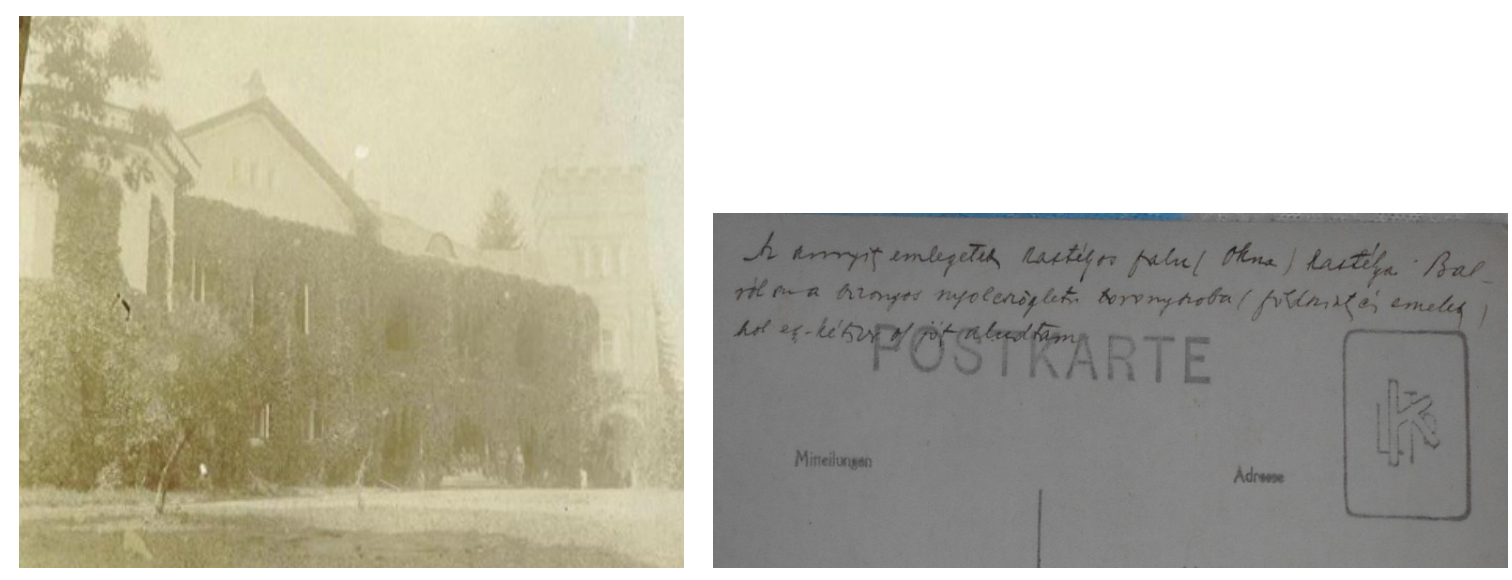

28-29. kép: Képeslap 
Okna „kastélyos faluról” láthatunk képet, amelyet szintén ellátott felirattal a kép hátulján. Azt írja, hogy balról a nyolcszögletü toronyban jót aludt egy-kétszer. Itt a szálláshelyét szerette volna megörökíteni családjának, illetve akár az utókor számára is. Mesterházy Jenő szerette megörökíteni azt, ahol éppen tartózkodott, amiket éppen ott látott - főleg épületeket, emlékműveket, szobrokat. Ezt a háború idején is gyakorolta, a képek hátuljára feljegyezéseket készítve.

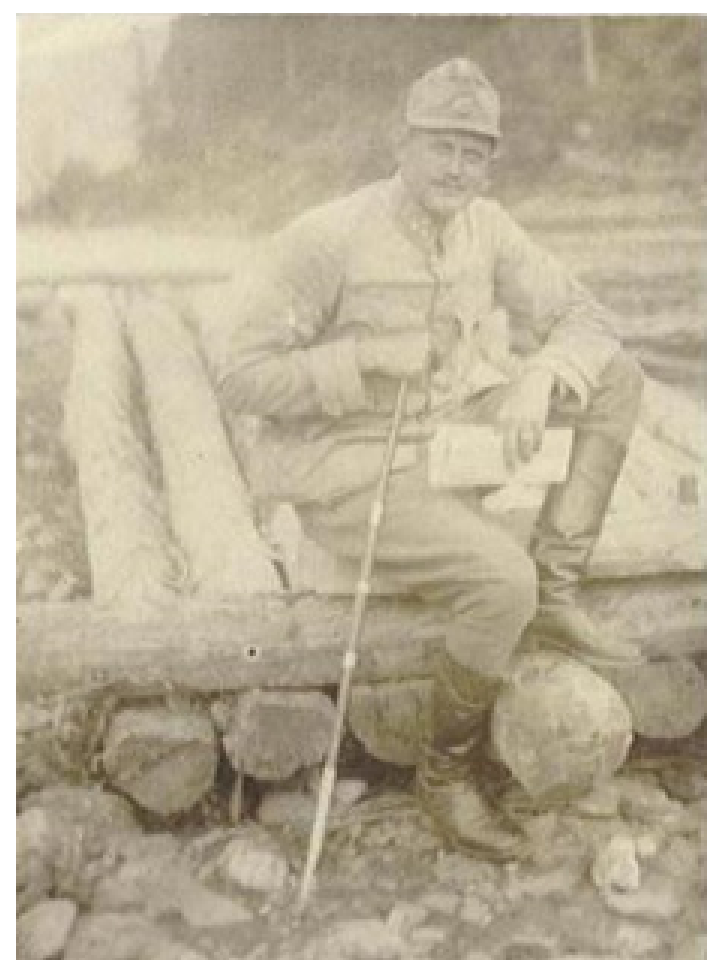

30. kép. Tutajon

Ezt a fotót is feleségének címezte meg, 1917. augusztus 28-ai dátummal. Nem isme- retes, hogy éppen milyen folyóparton üldögél egy fla tutajon és azt sem látni pontosan, hogy a kezében újságot tart-e avagy térképet a helyszínről, ahol éppen tartózkodnak. A bal kezén láthatjuk jegygyürűjét, amit - a kép tanúsága szerint - még a háború idején is viselt. Elgondolkodtató, hogy vajon szándékosan tartotta-e így a kezét, hogy feleségének megmutassa öszszetartozásuk tárgyi bizonyítékát vagy véletlenszerű volt a kéztartása. Az sem egészen egyértelmü, hogy a botot miért tartja a másik kezében, esetleg a rögös út könnyebbé tétele, tisztítása céljából. Ezen a képen nem sikerült Mesterházy Jenőt beazonosítani, így feltételezhető, hogy a fényképet ő készítette bajtársairól. Annyit viszont megtudhatunk, hogy 1917-ben készült ez a kép mégpedig Húsvét alkalmából. A kép címének a „Húsvéti barátkozást” adta a kép megőrzője. Ez egy nagyon felszabadult pillanatot ábrázol, többek kezében egy üveg italt láthatunk, valamint a középső férfinél még egy hegedü is van. A háttérben jobb oldalt sötétebb alakokat is láthatunk megbújni, ők elképzelhető, hogy egy másik csapathoz tartoztak és ezért nem álltak oda erre a képre, hanem megálltak oldalt, amíg elkészült a csoportkép. Erdei környezetet láthatunk, fenyőfákkal a háttérben. Az időpontból és a helyszínből következtethetünk arra, hogy ez ugyanaz a helyszín, ahol a fentebbi fatutajos kép is készült. Úgy tünik mindenesetre, hogy a katonák a húvsét ünnepét próbálták oldottan, vidáman eltölteni.

A háború időszakában is fontosnak tartotta, hogy tájékozódjon, így itt azt láthatjuk,

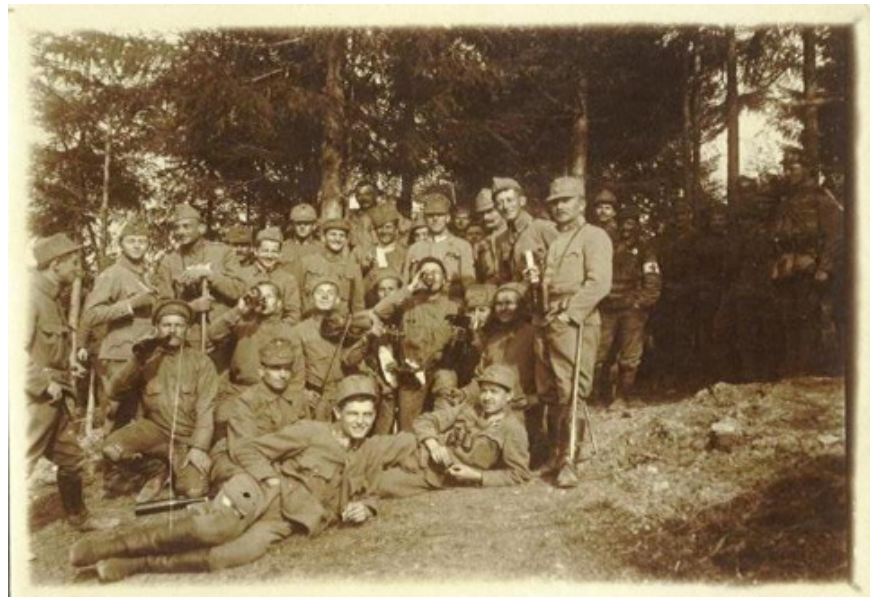

31. kép: Húsvéti barátkozás 
amint egy újságot tart a kezében és valószínűleg olvasta is a kép készítése előtt-után. 1917. szeptember 7-e a kép dátuma, amit megintcsak „kicsi mindenemnek” felirattal látott el. Nem lehet kiolvasni, hogy milyen folyóiratot tart a kezében, csak annyit, hogy valamilyen „lap”. Elképzelhető, hogy egy Pesti Hírlapot, de nem lehet biztos megállapítást tenni erre vonatkozóan. Nem derül ki az sem bővebben, hogy mi történik, hol és mit csinálnak egyébként. Nyugalmat sugároz a kép, legalábbis olyan benyomást kelt a rajta szereplő, Mesterházy. Nem tudjuk azt sem, hogy vajon ő kérte-e, hogy fotózzák le vagy valaki szívesen fotózgatta a jelen lévőket és így készültek a képek. Talán az első verzió mellett több érv szól, főképpen azért, mert a dokumentálási vágy egész életét jellemezte Mesterházynak, másrészről pedig az otthoniaknak szerette volna megmutatni, hogyan él ott.

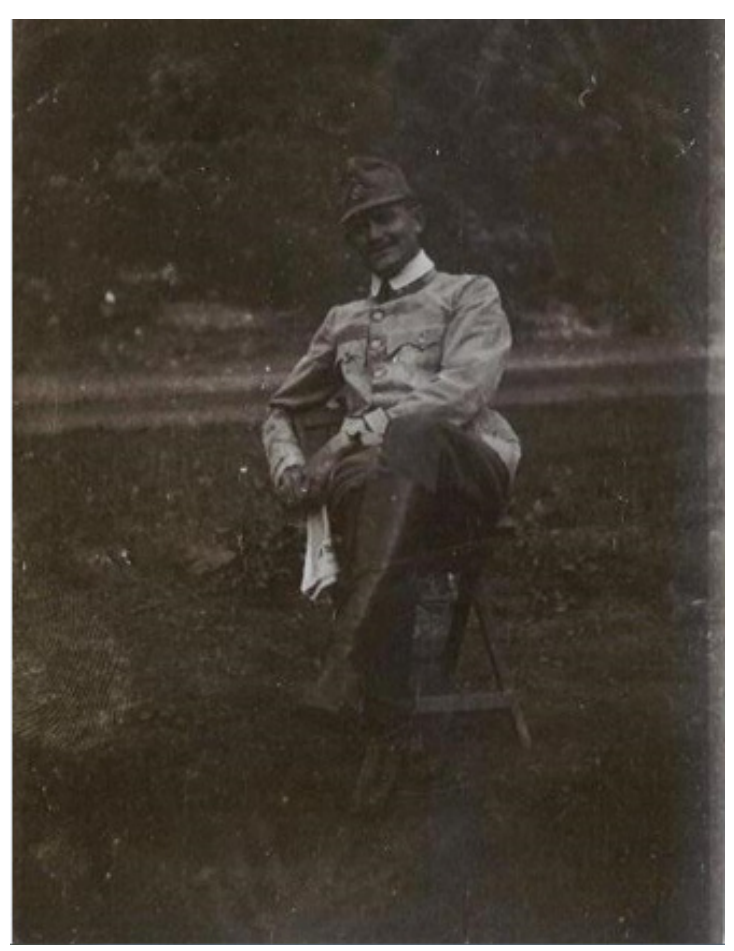

32. kép: Kicsi mindenemnek

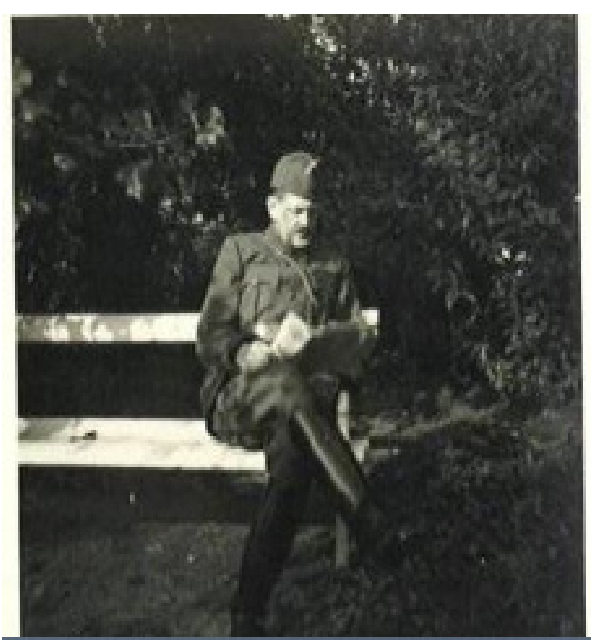

33-34. kép: A II. világháború időszaka
Nagy ugrás következik az időben, hiszen ezek a képek már a II. világháború időszakában készültek az idősebb Mesterházy Jenőről. Az első portré megintcsak valószínúleg egy bevonuláskor készített kép, ahogyan azt korábban láthattuk. Itt már keményebb, zordabb, tekintélyt parancsoló katonaférfi vonásait figyelhetjük meg, egyenruháját tekintve alhadnagyként (első tiszti rendfokozat). Nem tarthatta ezt az időszakot olyannyira meghatározónak életében (életrajzi adatok szerint nem is töltött három hónapnál többet a fronton), ezért nincs valószínűleg sok kép és egyikre sincs semmi írva, így nem tudhatjuk pontosan mikor és hol ké- szültek. Az 1940/41-es évkönyvben olvashatjuk csupán, hogy: „Miután 1940. július 2-ától október 2-ig tartó katonai szolgálata alatt, mint a 3. honv. dandár hadipénztár-fönöke részt vett a kelet-magyarországi bevonulásban, elnyerté a Kelet-Magyarország és Erdély egy részének felszabadulása emlékére alapított Erdélyi Emlékérmet." (Padányi, 1941. 13. o.). A másik képnél szintén az újságot olvasó férfit láthatjuk, akinek a tájékozódás a világ dolgairól minden bizonnyal fontos volt. Ez következhet abból is, hogy a történelem iránt mély vonzalmat érzett, így ezt a fajta érdeklődését minden körülmények között fenntartotta és igyekezett eleget tenni neki. 
Képekben elbeszélt múlt - Mesterházy Jenő

\section{A fotós}

Mesterházy Jenő nem csak a saját életét szerette fényképekkel dokumentálni, hanem az érdeklődési körébe tartozó témákat is megörökítette. A hagyaték anyagában található sok-sok fénykép Budapest különböző jellegzetes helyeiről (pl. Budai várnegyed, Duna-part), emléktáblákról, árvízi táblákról, templomokról. Ezeken kívül a művészetek is foglalkoztatták, így festmények- ről készített fotók is láthatók. Ezeket a képeit valószínủleg a népművelő és a tanítási tevékenysége során is alkalmazhatta, mint szemléltetést, hiszen a történelem és a földrajz fö területe volt.

Budai látkép valószínüleg a Gellért-hegy környékéről. Látható rajta a Duna és az azon átívelő Lánchíd, valamint a kivilágított Országház kupolája is. Nagyon szép, hangulatos esti felvétel, ami a fotósnak is tetszhetett, hiszen egy vastag karton képkeretet is kapott.

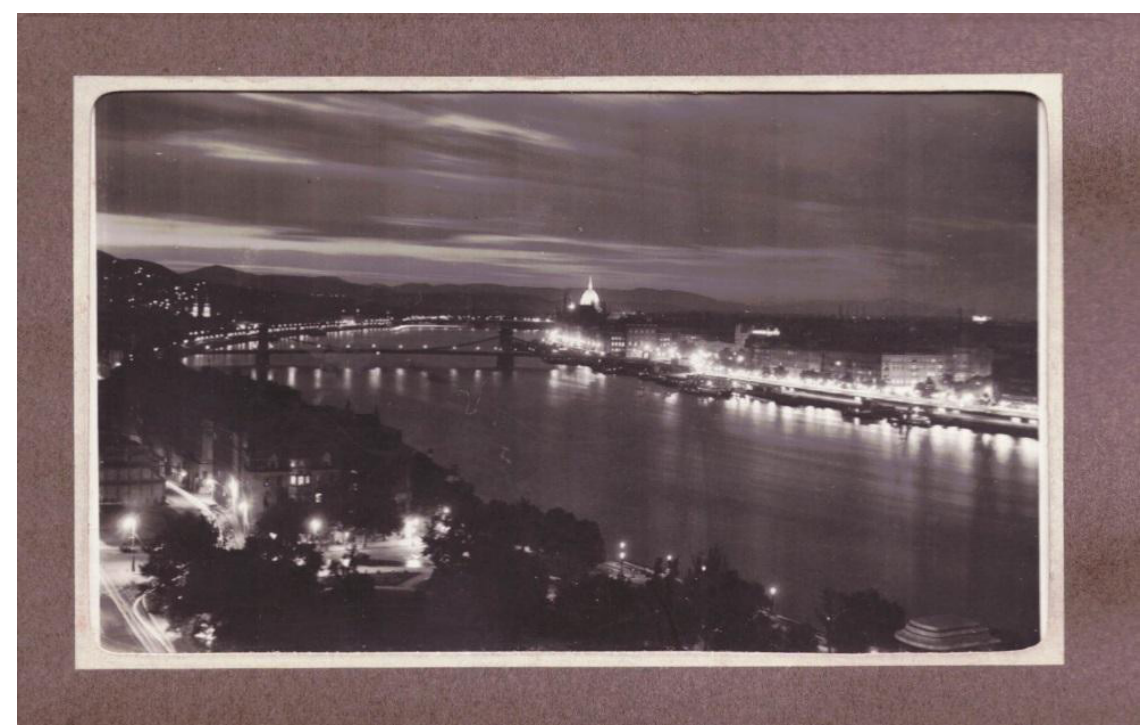

35. kép: Budai látkép
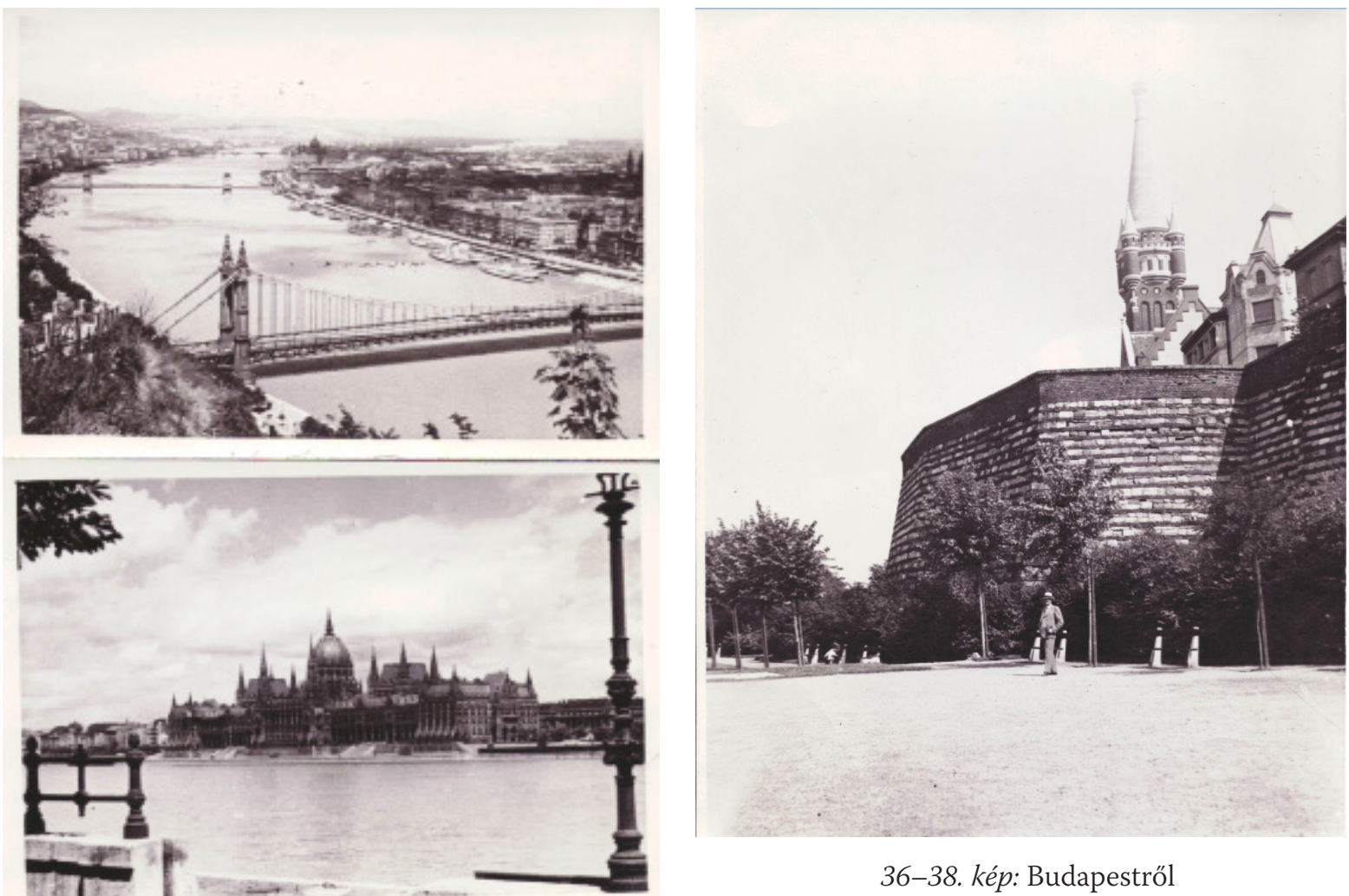
Ez a két kép szintén a belvárosról készült, az első külön érdekessége, hogy a második világháborúban felrobbantott Erzsébet- hidat még teljes valójában láthatjuk rajta. Pontos dátum nincs a fotón, viszont ebből valószínűsíthető, hogy még a második világháborút megelőzően készítette el Mesterházy. A második kép pedig a Batthyány tértől nem sokkal odébb készülhetett az Országházról. Szívesen örökítette meg a fővárost, érdeklődése középpontjában lehetett Budapest, hiszen számos képet találhatunk róla a hagyatékban. Figyelt a kép kompozíciójára, legalábbis ezekből azt szűrhetjük le, hogy nem csak készítette a képeket, hanem gondosan figyelt arra, hogy mi kerül a fotókra. A digitális fényképezés korszaka előtt jobban oda kellett ezekre a mozzanatokra figyelni, hiszen adott volt a képkockák darabszáma, amivel gazdálkodni lehetett

A Budai-várnál készült képen őt magát is láthatjuk a képen. Nem derül ki, hogy vala-
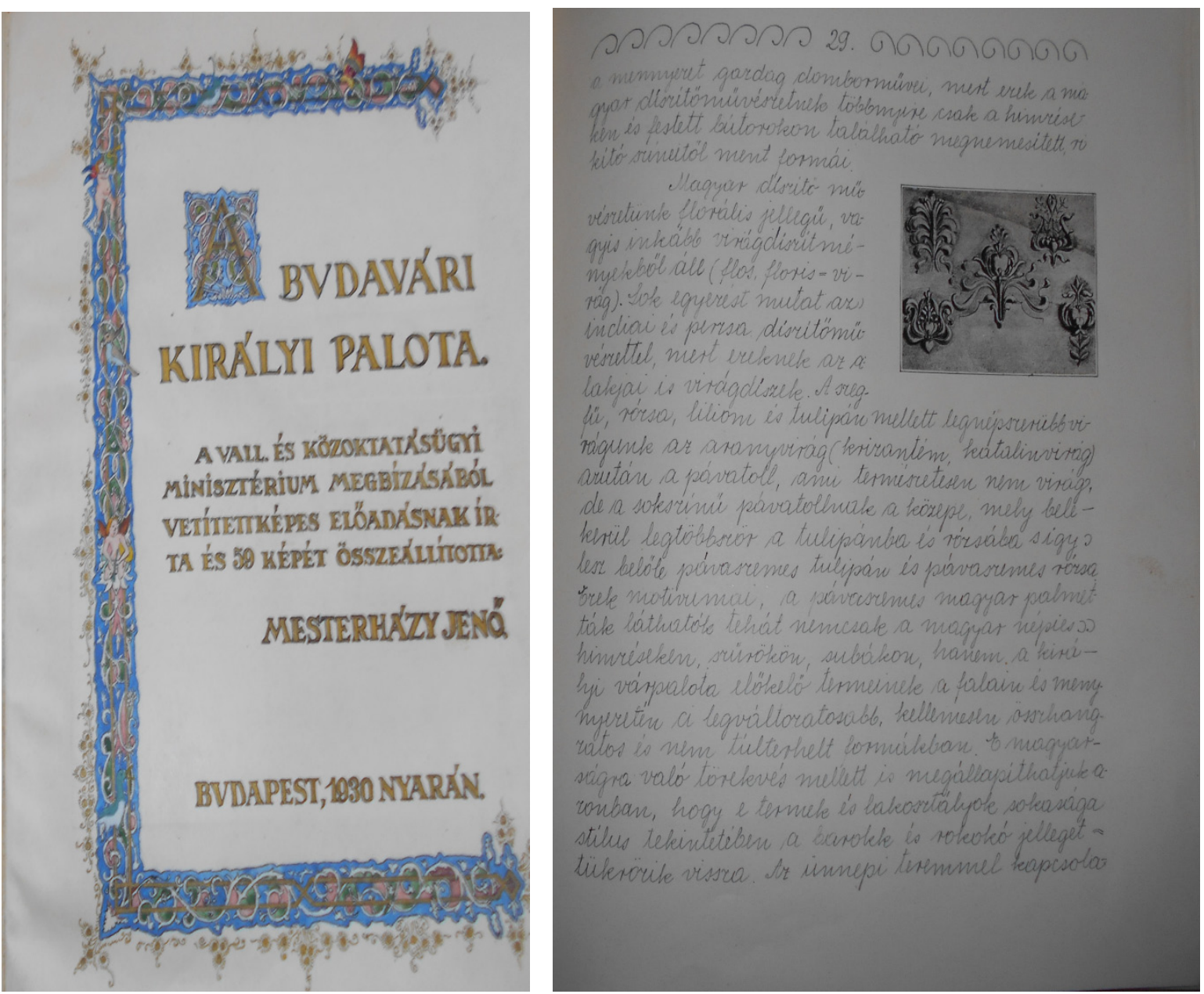

37-38. kép: A budavári előadás

kit megkért, hogy fényképezze le vagy pedig önkioldó segítségével készült a kép. Érdekes viszont, hogy szerette volna magát megörökíteni itt, hiszen a többi képeinél nem volt jellemző, hogy egyedül odaállt volna a helyszínen, ahol éppen fényképezett. Az is lehet, hogy ezt nem tanítási célzattal készítette, így inkább emlékként szerette volna megtartani, így magát is a képen látni. 1930-ban egy előadást is tartott a Budavári Királyi Palotáról, ami szintén a népmüvelő tevékenységét erősítette. Az előadásaihoz készített képei mind saját készítésűek voltak, amiből sejthető, hogy nagy érdeklődéssel volt azon témák iránt, amikről beszélt. Fontos lehetett számára, hiszen a munkájába fektetett energia erre a következtetésre engedtet. Ezen kívül a népművelés eszméje is végigkíséri éle- 
tét, hiszen pedagógusként is ilyen szerepkörre vállalkozott, de iskolán kívül is szívén viselte a nép müveltségének sorsát. A korszakában egy lelkes amatőr fotósnak tekinthetjük, hiszen a hagyaték anyagának több, mint negyede képi emlékeket tartalmaz, amelyek többségét saját kezűleg fotózta.

\section{Záró gondolatok}

Az Eötvös Loránd Tudományegyetem Tanító- és Óvóképző Karának Könyvtárában megbújó Mesterházy-hagyaték feldolgozására vállalkoztunk tanulmányunkban.

A hagyatékanyaggal történő első találkozásokkor igyekeztünk, csoportosítani, tematizálni, kategorizálni a rendelkezésünkre álló irat- és fotóállományt. Mesterházy Jenő személyes életéhez köthető, személyes életével kapcsolatos anyagokat csupán hiányosan leltük meg (egy korábban készített listáról kiderül, hogy például létező naplóinak száma sem teljes, a családtagjaira vonatkozó személyes, életrajzi adatok sem álltak rendelkezésünkre). Ennek ellenére hat föbb momentumot, meghatározó életeseményt is ki lehet emelni. Elsőként Mesterházy Jenőt mint családfőt, férjként és apaként. Megtudhattuk, hogy központi szerepet játszott életében a családja, mind a beleszületett (lásd levelei édesanyjának az első világháborúból), mind az általa alapított családja (lásd levelei a világháborúból, kirándulásairól feleségének, fényképei leányáról). Megállapíthatjuk, hogy Mesterházy igazán példaértékű értékeket vallott a családjához való ragaszkodást, szeretetet illetően. Az egyes képek hátuljára írt megjegyzéseiből érződik, hogy felesége egy nagyon erős, biztos pont az életében, akihez alig várta, hogy hazatérhessen a háborúból, akitől meleg szeretetet kapott és adott ő neki.

Természetesen szakmáját, de inkább hivatását is önálló kategóriaként, külön tárgyalandó részként tekintettük, hiszen egész aktív életében központi szerepet töltött be pedagógusi mestersége. Mesterházy Jenő tanítói és tanítóképezdei tanári végzettséget is szerzett élete során. Szakterülete a történelem, földrajz, magyar és torna volt, amit bizonyítanak kéziratai, egyetemi jegyzetei, a több e témában íródott publikációja, rádióelőadása, saját maga által készített képei, melyeket előszeretettel használt szemléltetésnek tanárként a tanítóképzőben.

Pedagógus vénája az iskolán kívüli tevékenységeiben is erőteljesen jelen volt, bizonyítja ezt a cserkészcsapatok vezetése és a népmüvelői tevékenysége, mely utóbbiért - ahogy már említettük - 1933-ban kitüntetést is kapott. A Budai Tanítóképzőben, ahol Mesterházy is tanárként tevékenykedett, 1927-ben alakult meg az Apáczai cserkészcsapat. Természetesen ő maga is részt vett a kirándulásokon a csapattal, ahol a cserkészet céljait figyelembe véve, valószínűleg az ifjak önállóságára, jellemformálására fektethették a hangsúlyt. A népművelés keretein belül hazai és külföldi kirándulásokat szervezett, melyeket ő maga koordinált, és az egyes helyszíneket ő maga mutatta be, a nevezetességekről ő maga beszélt, amiről a fotók is árulkodnak. És arról is árulkodnak, hogy Mesterházy Jenő valóban egy vezéregyéniség volt, vezetőtípus, szakértő, aki képes átadni tudását másoknak, akik figyelnek rá, hallgatják őt, mind a padsorok között lévők, mind az idősebb kiránduló, művelődni kívánó korosztály. Emellett egy határozott, dinamikus karakter lehetett, hiszen egyik népművelői kiránduláson készült fotón ${ }^{6}$ épp menet közben láthatjuk őt és a kiránduláson lévő többi embert, és az látszik, hogy határozottan, dinamikusan halad elöl a csapatban, nadrágszára lobog, közben pedig derűs arca látható.

Mesterházy Jenő megélte az első és második világháborút is, katonaként. Fotók leginkább az első világháborúból találhatók a rendelkezésünkre álló hagyatékot tekintve, melyek közül legtöbb szeretett feleségének van címezve a frontról, és melyekből érezni lehet, hogy alig várják, hogy viszontlássák egymást. A második világháború már nem töltött be olyan fontos szerepet életében, mint kiderült, 2 hónapot töltött katonaként ebben az időszakban és fotó sem készült róla nagy számmal.

${ }^{6}$ lásd: ELTE-TÓK Könyvtárában 
Mesterházy Jenő a tanár, népművelő, cserkészetvezető, katona, előadó, publikáló, férj, apa és nem utolsósorban fotós. Számos maga által készített fotót találhatunk a hagyatékanyaga között, beleértve épületeket, épületrészeket, szobrokat, festmények fotóit, árvíztáblák fotóit is, melyeket ő maga készített többek között tudományos előadásainak szemléltetéséhez (pl. üvegdia-vetítéssel vagy publikációkban), és melyek tükrözik történelem- és földrajzszeretetét. Ez az ő korában igen különleges módszernek számított, ő maga egy vizuális alkat lehetett. Amatőr fotós volt, aki igen jól beállított képeket készített, mondhatni nem egyszer ikonográfiai kutatást végzett (pl. régi és az ő korában meglévő Bautzeni-dombormű kinézetének összevetése).

Mesterházy Jenő életének főbb momentumainak áttekintése nagyon jól reprezentálja azt, hogy bár egy "hétköznapi pedagógusról" van szó, mégis mennyi mindennel foglalkozott, mennyi mindent elért a hivatását tekintve. Élete annyiban tekinthető tipikusnak, hogy a Tanítóképző Intézeti tanári tevékenységét lelkiismerettel végezte, és törekedett szakmai fejlődésére. Illetve a korabeli viszonyokat figyelembe véve, a katonaként háborúba való kötelező besorolása is általános jelenségnek volt tekinthető. Életének atipikus elemeihez tartozik különleges fotós tevékenysége, melynek során a korabeli helyszíneket, szobrokat, építményeket megörökítette és tanári munkássága során fel is használta azokat előadásai színesítésére. Továbbá a sokrétű iskolán kívüli tevékenységei is, mint például a TITOE-ban végzett munkája, a cserkészcsapat-vezető és népművelő tevékenysége.

Elmondhatjuk, hogy Mesterházy Jenő egy sokoldalú, tevékeny ember volt, akinek családja mellett hivatása is kiemelkedő szereppel bírt életében. Megállapíthatjuk, hogy hagyatékában kevés a hivatalos kép, inkább magánfotókat találhatunk, a pedagógus keze által készítetteket leginkább. Jó kapcsolatot ápolhatott az emberekkel (lásd képeslapok, melyeket tanítványaitól kapott, kirándulások, ahol figyelnek szavaira az emberek, előadásokon, rádióelőadásokon való fellépése, tevékenységéért kapott elismerések, kitüntetések), tehát pedagógusként sem lehetett mogorva, nehéztermészetű ember. Portréfotói megvizsgálásakor látszik, ahogy az idők során folyamatosan változott a testtartása, mintegy idősödő, kissé megfáradt, ámde derűs idős úr képét láthatjuk késői fotóin. Mesterházy Jenő halála után fél évszázaddal megállapíthatjuk, hogy személyisége, derűssége, családszeretete, hivatástudata, tevékenységei ma is példaértékűnek számítanak, és jelen hagyaték-feldolgozás is azon kívül, hogy bemutat egy kevéssé ismert, 20. században aktív pedagógusi életpályát ikonográfiai elemekkel színezve, példaként is interpretálja Mesterházy Jenő tevékeny és termékeny tudományos- és magánéletét egyaránt, akár a leendő pedagógusjelöltek számára, akár más szakmát gyakorlók számára is.

Köszönet az ELTE PPK kutatás-támogatási pályázatának és az ELTE-TÓK Könyvtárának az anyagok hozzáféréséért, felhasználásáért és segítségükért!

\section{Felhasznált irodalom}

\section{Elsődleges források}

Mesterházy Jenő kéziratai, fotói, jegyzetei, tárgyi emlékei

Padányi-Frank Antal (1929): A budapesti Magy. Kir. Állami Elemi Népiskolai Tanítóképző-intézet Értesítője az 1929-30. évi értesítője. Budapest.

Padányi-Frank Antal (1931): A budapesti Magy. Kir. Állami Elemi Népiskolai Tanítóképző-intézet Értesítője az 1930-31. évi értesítője. Budapest.

Padányi-Frank Antal (1937): A budapesti I. kerületi Magy. Kir. Állami népiskolai Tanítóképzőintézet Értesítője az 1936-37. iskolai évről. Budapest.

Padányi-Frank Antal (1940): A budapesti Magy. Kir. Állami líceum és Tanítóképző-intézet évkönyve az 1939-40. iskolai évről. Budapest.

Padányi-Frank Antal (1941): A budapesti Magy. Kir. Állami líceum és Tanítóképző-intézet évkönyve az 1940-41. iskolai évről. Budapest.

Padányi-Frank Antal (1942): A budapesti Magy. Kir. Állami líceum és Tanítóképző-intézet évkönyve az 1941-42. iskolai évről. Budapest.

http://www.1000ev.hu/index.php?a=3\& param=8068 (utolsó letöltés: 2015-10-27) 
Képekben elbeszélt múlt - Mesterházy Jenő

\section{Másodlagos források}

Endrődy-Nagy Orsolya (2015): A reneszánsz gyermekképe-a gyermekkép reneszánsza 1455 1517 között Európában-ikonográfiai elemzés. Doktori disszertáció, Takács Etel Pedagógiai Alapítvány - Eötvös kiadó, Budapest.

Géczi János (2010): Ikonológia-ikonográfia mint a történeti pedagógia segédtudománya URL: http://mek.oszk.hu/08400/08438/08438. pdf

Hirsch, Julia (2000): Családi képek. Tartalom, jelentés, értelem. In: Családi album. Vizuális antropológiai szöveggyüjtemény I., Miskolci Egyetemi KiadÓ, Miskolc, 70-110.

Kovács Krisztina (2011): A Néptanítói szakmásodás alakulása két dualizmus kori neveléstan-könyv tanítóképének elemzése tükrében. In: Magyar Pedagógia, 111. 4. sz., 289-311.

URL: http://www.magyarpedagogia.hu/ document/Kovacs_MP1114.pdf

Kövér György (2000): Biográfia és történetírás. URL: http://epa.oszk.hu/00800/00861/00015/ 2000 3-10.html

Mikonya György (2006): Pedagógiai életképek az 1945 utáni magyar nevelés történetéből. In: Szabolcs Éva: Pedagógia és politika a XX. század második felében Magyarországon. Eötvös József Könyvkiadó, Budapest, 54-114.
Mikonya György (2011): Életút-elemzés és ikonográfia alkalmazása a nevelés történetében. In: Tölgyesy József (szerk.), A modern pedagógia új dimenziói, Kodolányi János Főiskola, Székesfehérvár, 79-90.

Panyik Ilona (1991): A Budapesti Tanítóképző Főiskola. Budapesti Tanítóképző Főiskola, Budapest.

Pénzes Dávid (2013): A biográfiai módszer a pedagógiatörténeti kutatásban

URL: http://pedagogiatortenet.elte.hu/ wp-content/uploads/2013/11/abszt201311. pdf

Pornói Imre (é.n.): Tanitóképzés és népoktatás

URL: www.nyf.hu/fakultas/szocped/ publikaciok/Tanitokepzes

Pukánszky Béla és Németh András (2011): Neveléstörténet

URL: http://magyar-irodalom.elte.hu/ nevelestortenet/09.02.html

Raicsné dr. Horváth Anikó PhD (é.n.): Az Óvó- és Tanitóképzők Egyesületének (ÓTE) müködése. URL: http://www.ote1992.hu/egyesulet

Somogyvári Lajos (2013): A szakmai kommunikáció képi megjelenítései (1960-1970)

URL: http://nevelestudomany.elte.hu/index. php/2013/10/a-szakmai-kommunikacio-kepimegjelenitesei-1960-1970/\#more-1355

\section{Past told in Pictures - Jenő Mesterházy}

The authors' research of the inheritance was made within the framework of a research proposal supported by ELTE Faculty of Education and Psychology in 2015. The Mesterházyinheritance can be found at the library of ELTE Faculty of Primary and Pre-School Education, where the examination made upon the research was also carried out. In this study the authors' aim was to discover and give a better view on an 'ordinary pedagogue's' paths of life in order to present a model or pattern for all pedagogues in present and also in the future. Analysis of personal documents and experiences might also help in emerging in details of a historical period. Mesterházy put great effort into documenting his life and career paths, he kept a lot of scripts beside the printed papers (publications, notes of his lectures, radio performances, diaries) and also his private and professional correspondence was carefully preserved containing his huge collection of photographs. The authors present the pedagogue's life through six major topics, by the method of document analysis and iconography: Mesterházy Jenö as Husband and Father; Pedagogue; a Head of a Scout Team; a Leader of Cultural activities; The Soldier and Mesterházy as a Photographer.

Keywords: inheritance research, document analysis, iconography, life path, pedagogue

Janek Noémi és Balog Beáta (2017): Képekben elbeszélt múlt - Mesterházy Jenő. Gyermeknevelés, 5. 1. sz., 85-109. 